\title{
Impact of a moderate volcanic eruption on chemistry in the lower stratosphere: balloon-borne observations and model calculations
}

\author{
Gwenaël Berthet $^{1}$, Fabrice Jégou ${ }^{1}$, Valéry Catoire ${ }^{1}$, Gisèle Krysztofiak ${ }^{1}$, Jean-Baptiste Renard ${ }^{1}$, Adam E. Bourassa ${ }^{2}$, \\ Doug A. Degenstein ${ }^{2}$, Colette Brogniez ${ }^{3}$, Marcel Dorf ${ }^{4, a}$, Sebastian Kreycy ${ }^{4}$, Klaus Pfeilsticker ${ }^{4}$, Bodo Werner ${ }^{4}$, \\ Franck Lefèvre $^{5}$, Tjarda J. Roberts ${ }^{1}$, Thibaut Lurton ${ }^{1}$, Damien Vignelles ${ }^{1}$, Nelson Bègue ${ }^{6}$, Quentin Bourgeois ${ }^{7}$, \\ Daniel Daugeron $^{1}$, Michel Chartier ${ }^{1}$, Claude Robert $^{1}$, Bertrand Gaubicher $^{1}$, and Christophe Guimbaud ${ }^{1}$ \\ ${ }^{1}$ Laboratoire de Physique et Chimie de l'Environnement et de l'Espace (LPC2E), Université d'Orléans, \\ CNRS UMR7328, Orléans, France \\ ${ }^{2}$ Institute of Space and Atmospheric Studies, University of Saskatchewan, Saskatoon, Canada \\ ${ }^{3}$ Laboratoire d'Optique Atmosphérique, Université Lille 1 Sciences et Technologies, CNRS UMR8518, \\ Villeneuve d'Ascq, France \\ ${ }^{4}$ Institute of Environmental Physics, University of Heidelberg, Heidelberg, Germany \\ ${ }^{5}$ Laboratoire Atmosphères Milieux Observations Spatiales, UPMC, Université Paris 06, \\ Université Versailles Saint Quentin, CNRS UMR8190, LATMOS-IPSL, Paris, France \\ ${ }^{6}$ Laboratoire de l'Atmosphère et des Cyclones, UMR8105 CNRS, Université de la Réunion, Saint-Denis de la Réunion, \\ France \\ ${ }^{7}$ Department of Meteorology and Bolin Centre for Climate Research, Stockholm University, Stockholm, Sweden \\ anow at: Max Planck Institute for Chemistry, Department of Atmospheric Chemistry, Mainz, Germany
}

Correspondence to: Gwenaël Berthet (gwenael.berthet@cnrs-orleans.fr)

Received: 23 August 2016 - Discussion started: 14 September 2016

Revised: 7 January 2017 - Accepted: 12 January 2017 - Published: 14 February 2017

\begin{abstract}
The major volcanic eruption of Mount Pinatubo in 1991 has been shown to have significant effects on stratospheric chemistry and ozone depletion even at midlatitudes. Since then, only "moderate" but recurrent volcanic eruptions have modulated the stratospheric aerosol loading and are assumed to be one cause for the reported increase in the global aerosol content over the past 15 years. This particularly enhanced aerosol context raises questions about the effects on stratospheric chemistry which depend on the latitude, altitude and season of injection. In this study, we focus on the midlatitude Sarychev volcano eruption in June 2009, which injected $0.9 \mathrm{Tg}$ of sulfur dioxide (about 20 times less than Pinatubo) into a lower stratosphere mainly governed by high-stratospheric temperatures. Together with in situ measurements of aerosol amounts, we analyse high-resolution in situ and/or remote-sensing observations of $\mathrm{NO}_{2}, \mathrm{HNO}_{3}$ and $\mathrm{BrO}$ from balloon-borne infrared and UV-visible spectrometers launched in Sweden in August-September 2009. It is shown that differences between observations and three-
\end{abstract}

dimensional (3-D) chemistry-transport model (CTM) outputs are not due to transport calculation issues but rather reflect the chemical impact of the volcanic plume below $19 \mathrm{~km}$ altitude. Good measurement-model agreement is obtained when the CTM is driven by volcanic aerosol loadings derived from in situ or space-borne data. As a result of enhanced $\mathrm{N}_{2} \mathrm{O}_{5}$ hydrolysis in the Sarychev volcanic aerosol conditions, the model calculates reductions of $\sim 45 \%$ and increases of $\sim 11 \%$ in $\mathrm{NO}_{2}$ and $\mathrm{HNO}_{3}$ amounts respectively over the August-September 2009 period. The decrease in $\mathrm{NO}_{x}$ abundances is limited due to the expected saturation effect for high aerosol loadings. The links between the various chemical catalytic cycles involving chlorine, bromine, nitrogen and $\mathrm{HO}_{x}$ compounds in the lower stratosphere are discussed. The increased $\mathrm{BrO}$ amounts $(\sim 22 \%)$ compare rather well with the balloon-borne observations when volcanic aerosol levels are accounted for in the CTM and appear to be mainly controlled by the coupling with nitrogen chemistry rather than by enhanced $\mathrm{BrONO}_{2}$ hydrolysis. We show 
that the chlorine partitioning is significantly controlled by enhanced $\mathrm{BrONO}_{2}$ hydrolysis. However, simulated effects of the Sarychev eruption on chlorine activation are very limited in the high-temperature conditions in the stratosphere in the period considered, inhibiting the effect of $\mathrm{ClONO}_{2}$ hydrolysis. As a consequence, the simulated chemical ozone loss due to the Sarychev aerosols is low with a reduction of $-22 \mathrm{ppbv}$ $(-1.5 \%)$ of the ozone budget around $16 \mathrm{~km}$. This is at least 10 times lower than the maximum ozone depletion from chemical processes (up to $-20 \%$ ) reported in the Northern Hemisphere lower stratosphere over the first year following the Pinatubo eruption. This study suggests that moderate volcanic eruptions have limited chemical effects when occurring at midlatitudes (restricted residence times) and outside winter periods (high-temperature conditions). However, it would be of interest to investigate longer-lasting tropical volcanic plumes or sulfur injections in the wintertime lowtemperature conditions.

\section{Introduction}

In the stratosphere, the photo-oxidation of $\mathrm{N}_{2} \mathrm{O}$ is the main source of all nitrogen species $\left(\mathrm{NO}_{y}\right)$. About $97 \%$ of the stratospheric $\mathrm{NO}_{y}$ budget can be explained by $\mathrm{NO}, \mathrm{NO}_{2}$, $\mathrm{HNO}_{3}, \mathrm{ClONO}_{2}$, and $\mathrm{N}_{2} \mathrm{O}_{5}$ compounds, and the partitioning between reactive and reservoir nitrogen species is an important issue in stratospheric ozone chemistry (e.g. Wetzel et al., 2002; Brohede et al., 2008). Nitrogen oxides $\left(\mathrm{NO}_{x}=\mathrm{NO}+\mathrm{NO}_{2}\right)$ are major catalysts responsible for significant ozone destruction in the middle stratosphere. In the gas phase, $\mathrm{NO}_{x}$ interacts with the hydrogen and halogen species in catalytic cycles affecting ozone loss rates in the lower stratosphere (e.g. Portmann et al., 1999; Salawitch et al., 2005). Therefore, $\mathrm{NO}_{x}$ can also buffer the ozone destruction by halogenated compounds through the formation of $\mathrm{ClONO}_{2}$ and $\mathrm{BrONO}_{2}$ (e.g. Rivière et al., 2004). The $\mathrm{HNO}_{3}$ reservoir is formed from $\mathrm{NO}_{x}$ indirectly via the hydrolysis of $\mathrm{N}_{2} \mathrm{O}_{5}$ on liquid sulfate aerosols:

$\mathrm{N}_{2} \mathrm{O}_{5}+\mathrm{H}_{2} \mathrm{O}_{(\mathrm{aq})} \rightarrow 2 \mathrm{HNO}_{3}$.

It has been shown that models need to include Reaction (R1) to better reproduce observations of $\mathrm{NO}_{y}$ partitioning at midlatitude for background aerosol conditions (i.e. in volcanically quiescent periods) in the lower stratosphere (Rodriguez et al., 1991; Granier and Brasseur, 1992; Fahey et al., 1993; Webster et al., 1994; Salawitch et al., 1994b; Sen et al., 1998). This reaction tends to decrease $\mathrm{NO}_{x}$ amounts and reduces the ozone loss efficiency associated with the $\mathrm{NO}_{x}$ catalytic cycle as the less reactive nitrogen reservoir $\mathrm{HNO}_{3}$ is formed (e.g. Rodriguez et al., 1991; Weisenstein, 1991; McElroy et al., 1992). Reaction (R1) is fairly insensitive to temperature and has the potential to greatly reduce reactive nitrogen globally, even under background aerosol conditions.
The hydrolysis of $\mathrm{ClONO}_{2}$ can be expressed by

$\mathrm{ClONO}_{2}+\mathrm{H}_{2} \mathrm{O}_{(\mathrm{aq})} \rightarrow \mathrm{HNO}_{3}+\mathrm{HOCl}$.

It results in the additional formation of $\mathrm{HNO}_{3}$ on sulfate aerosols and in the formation of reactive chlorine in sunlight, where $\mathrm{HOCl}$ is rapidly photolysed releasing $\mathrm{Cl}$ radicals (e.g. Hofmann and Solomon, 1989; Prather, 1992; McElroy et al., 1992). This heterogeneous reaction is highly dependent on the water content in the aerosols and has been shown to be of considerable importance in determining the abundance of active chlorine available to destroy ozone under some conditions, i.e. for temperatures typically below $210-215 \mathrm{~K}$ and where $\mathrm{HNO}_{3}$ photolysis rates are slow (typically in winter at high latitudes) (e.g. Hanson et al., 1994; Tie et al., 1994; Borrmann et al., 1997). However, for higher temperatures the $\mathrm{ClONO}_{2}$ hydrolysis is not expected to be significant enough to compete with Reaction (R1) on the $\mathrm{NO}_{y}$ partitioning under these conditions (Fahey et al., 1993; Cox et al., 1994; Sen et al., 1998). Also, the reaction

$\mathrm{ClONO}_{2}+\mathrm{HCl}_{(\mathrm{aq})} \rightarrow \mathrm{HNO}_{3}+\mathrm{Cl}_{2}$

of $\mathrm{ClONO}_{2}$ with dissolved $\mathrm{HCl}$ in sulfuric acid droplets has negligible effects on chlorine activation at such temperatures (Hanson et al., 1994; Borrmann et al., 1997).

Some works also suggest that the hydrolysis of $\mathrm{BrONO}_{2}$,

$\mathrm{BrONO}_{2}+\mathrm{H}_{2} \mathrm{O}_{(\mathrm{aq})} \rightarrow \mathrm{HNO}_{3}+\mathrm{HOBr}$,

on background sulfate aerosols also plays a significant role in ozone depletion in the lower stratosphere with rates almost independent of temperature, making this reaction efficient at all latitudes and for all seasons (Hanson and Ravishankara, 1995; Hanson et al., 1996; Lary et al., 1996; Randeniya et al., 1997; Erle et al., 1998).

After large volcanic eruptions, the aerosol loading in the stratosphere and the surface area densities (hereafter SADs) available for Reaction (R1) to occur are dramatically enhanced (e.g. Deshler et al., 2003). As a result, the amount of ozone-depleting $\mathrm{NO}_{x}$ is strongly reduced (e.g. Prather, 1992; Johnston et al., 1992; Fahey et al., 1993; Mills et al., 1993; Solomon et al., 1994; Kondo et al., 1997; Sen et al., 1998; Dhomse et al., 2015), whereas $\mathrm{HNO}_{3}$ amounts increase (Koike et al., 1993, 1994; Webster et al., 1994; Rinsland et al., 2003) as shown for the Pinatubo aerosols. Different chemical impacts on stratospheric ozone are expected depending on the altitude. In the middle stratosphere (above $\sim 30 \mathrm{hPa}$ ), where ozone loss is dominated by $\mathrm{NO}_{x}$, the presence of volcanic aerosols can result in layers of increased net production of ozone due to the suppression of the $\mathrm{NO}_{x}$ cycle by the $\mathrm{N}_{2} \mathrm{O}_{5}$ hydrolysis (Hofmann et al., 1994; Bekki and Pyle, 1994; Tie and Brasseur, 1995). In the lower stratosphere, halogen $\left(\mathrm{ClO}_{x}\right.$ and $\left.\mathrm{BrO}_{x}\right)$ and hydrogen $\left(\mathrm{HO}_{x}\right)$ radicals play a dominant role in ozone depletion, and their abundances, which depend on $\mathrm{NO}_{x}$ levels, are increased (in particular for halogen species, as the rate of gas-phase conversion of $\mathrm{ClO}$ into the $\mathrm{ClONO}_{2}$ reservoir is reduced), resulting 
in an enhanced catalysed ozone loss (McElroy et al., 1992; Granier and Brasseur, 1992; Brasseur and Granier, 1992; Hofmann et al., 1994; McGee et al., 1994; Bekki and Pyle, 1994; Salawitch et al., 1994a, 2005; Tie et al., 1994; Solomon et al., 1996; Solomon, 1999).

However, the $\mathrm{NO}_{x}$-to- $\mathrm{HNO}_{3}$ conversion by Reaction (R1) shows saturation as the aerosol SAD increases because the amount of $\mathrm{N}_{2} \mathrm{O}_{5}$ present in the stratosphere is limited by its production rate by the gaseous reaction $\mathrm{NO}_{2}+\mathrm{NO}_{3}(\mathrm{Fa}-$ hey et al., 1993; Prather, 1992; Mills et al., 1993; Tie et al., 1994; Solomon et al., 1996; Kondo et al., 1997; Sen et al., 1998). Consequently, ozone loss rates are expected to be limited because the saturation of the $\mathrm{NO}_{x} / \mathrm{NO}_{y}$ response to the aerosol increase dampens the increase in $\mathrm{ClO} / \mathrm{Cl}_{y}$ (Fahey et al., 1993; Tie et al., 1994). Reaction (R2) does not show such a rapid saturation resulting in enhanced ozone depletion by chlorine catalytic cycles in cold air masses as the aerosol loading increases (Fahey et al., 1993). The $\mathrm{BrONO}_{2}$ hydrolysis through Reaction (R4) is primarily dependent on the aerosol loading and is enhanced in periods of high volcanic aerosol loading. The resulting increase in $\mathrm{BrO}_{x}$ and $\mathrm{HO}_{x}$ radical concentrations and decrease in $\mathrm{HCl}$ (due to enhanced $\mathrm{OH}$ ) accompanied by an increase in $\mathrm{ClO}_{x}$ radicals is expected to give further ozone loss in the lower stratosphere at all latitudes and seasons (Lary et al., 1996).

In periods following major eruptions, the year-to-year variability in stratospheric ozone at northern midlatitudes appears closely linked to dynamical changes induced by the volcanic aerosol radiative perturbation (e.g. Telford et al., 2009; Aquila et al., 2013) and to changes in chlorine partitioning (e.g. Solomon, 1999; Chipperfield, 1999). Effects on stratospheric chemistry are expected in periods of elevated chlorine levels from anthropogenic activities (Tie and Brasseur, 1995; Solomon et al., 1996). In the past decade no event comparable to the 1991 Pinatubo or 1982 El Chichón eruptions was observed. However, several volcanic eruptions, though of much lesser amplitude, impacted the aerosol burden in the lower stratosphere over periods of months (Vernier et al., 2011). These "moderate" eruptions have occurred in a period of still high chlorine loading with a potential impact on stratospheric ozone chemistry. Their effects depend on the amount of released $\mathrm{SO}_{2}$ and on latitudes and altitudes of injection which directly influence aerosol residence times. The season of the eruption is also important for photochemical processes which are directly connected to temperatures and solar illumination.

The goal of this paper is to show how such moderate eruptions are likely to modify the chemical balance of the Northern Hemisphere lower stratosphere at periods excluding wintertime or springtime halogen-activating photochemistry. We specifically focus on the eruption of the Sarychev volcano on 15 and 16 June 2009, which injected $0.9 \mathrm{Tg}$ of sulfur dioxide into the lower stratosphere (Clarisse et al., 2012), resulting in enhanced sulfate aerosol loading up to $19 \mathrm{~km}$, for a period of about 8 months ending before winter (Haywood et al., 2010; Kravitz et al., 2011; O'Neill et al., 2012; Jégou et al., 2013).

The approach consists in analysing some key aspects of lower-stratospheric chemistry and ozone loss in a context of high aerosol surface area densities and high-stratospheric temperatures using balloon-borne observations conducted in August-September 2009 from Kiruna/Esrange in Sweden $\left(67.5^{\circ} \mathrm{N}, 21.0^{\circ} \mathrm{E}\right)$ within the frame of the StraPolÉté project. To our knowledge we show here the first high-resolution in situ observations of chemical compounds obtained within the volcanic aerosol plume of a moderate eruption. We show that in the period on which the study is focused, $\mathrm{N}_{2} \mathrm{O}_{5}$ had reformed and the role of its hydrolysis became important again after the sunlit summer period, justifying the use of these balloon data for the investigation of heterogeneous processes. Aerosol-constrained simulations using a 3-D chemistry transport model (CTM) are compared to the observations. These model calculations ignore possible dynamical effects induced by the volcanic aerosols but are used to estimate the amplitude of the chemical impacts and ozone loss with some comparisons with the post-Pinatubo eruption period.

\section{Methodology}

\subsection{Balloon-borne observations}

Our study is based on in situ and remote-sensing balloonborne observations obtained during summer 2009 in northern Sweden. More details about the instrument descriptions and retrieval techniques are given in the Appendix and in the references. Data can be found in ESPRI data Centre (2016).

\subsubsection{In situ observations}

Aerosol in situ measurements were performed by the STAC (Stratospheric and Tropospheric Aerosol Counter) instrument which is an optical particle counter providing aerosol size distributions (Ovarlez and Ovarlez, 1995; Renard et al., 2008). This instrument has been used in a number of studies dedicated to the quantification of the aerosol content in the stratosphere at various locations and seasons (e.g. Renard et al., 2002, 2005, 2010). Eight vertical aerosol concentration profiles were obtained between August and September 2009 as reported by Jégou et al. (2013).

Our study presents in situ vertical profiles of the $\mathrm{N}_{2} \mathrm{O}, \mathrm{NO}_{2}$ and $\mathrm{HNO}_{3}$ gases as observed by SPIRALE (SPectroscopie InfraRouge d'Absorption par Lasers Embarqués; Moreau et al., 2005) from two balloon flights. Firstly, the measurements during the 7 August 2009 flight (called SPIRALE-07082009 below) were conducted between 02:00 UT (04:00 local time) and 03:20 UT (05:20 local time), corresponding to altitudes of 14 and $34 \mathrm{~km}$ respectively. The position of the balloon varied from $67.72^{\circ} \mathrm{N}-21.40^{\circ} \mathrm{E}$ to $67.63^{\circ} \mathrm{N}-20.92^{\circ} \mathrm{E}$ during the ascent. Secondly, for the SPIRALE balloon flight on $24 \mathrm{Au}-$ 
gust 2009 (called SPIRALE-24082009 below), the measurements started at 21:00 UT (23:00 local time) at an altitude of $14 \mathrm{~km}$ and the maximum altitude of $34 \mathrm{~km}$ was reached at 22:30 UT (00:30 local time). The measurement position remained rather constant during the ascent with a displacement of the balloon from $67.91^{\circ} \mathrm{N}-21.09^{\circ} \mathrm{E}$ to $67.86^{\circ} \mathrm{N}-$ $20.94^{\circ} \mathrm{E}$. The data used in this study are averaged over a vertical range of $250 \mathrm{~m}$ (corresponding to $\sim 1 \mathrm{~min}$ of measurements).

\subsubsection{Remote-sensing observations}

Since 1996 stratospheric $\mathrm{NO}_{2}$ and $\mathrm{BrO}$ have been measured by solar occultation by the DOAS (differential optical absorption spectroscopy) balloon-borne instrument using the DOAS technique (e.g. Platt, 1994; Stutz and Platt, 1996; Ferlemann et al., 2000). The details of the vertical profile retrieval can be found in Butz et al. (2006) for $\mathrm{NO}_{2}$ and in Harder et al. (1998), Aliwell et al. (2002), Dorf et al. (2006b) and Kreycy et al. (2013) for BrO. In our study we use the DOAS profile recorded in the stratosphere during the balloon ascent on 7 September 2009 between 15:15 UT (17:15 local time) and 16:35 UT (18:35 local time), corresponding to altitudes of 10 and $30 \mathrm{~km}$ respectively.

The SALOMON (Spectroscopie d'Absorption Lunaire pour l'Observation des Minoritaires Ozone et $\mathrm{NO}_{x}$ ) balloonborne UV-visible spectrometer also uses the DOAS method to derive the mixing ratio profile of $\mathrm{NO}_{2}$ (Renard et al., 2000; Berthet et al., 2002). SALOMON was initially based on the lunar occultation technique, but on 25 August 2009, we flew a new version also able to use the Sun as a direct light source to derive $\mathrm{BrO}$ amounts. The profiles used in this study were obtained on 25 August 2009 during solar occultation between 18:50 UT (20:50 local time) and 19:30 UT (21:30 local time). The float altitude was $33 \mathrm{~km}$, and the position of the tangent point varied from $71.0^{\circ} \mathrm{N}-13.3^{\circ} \mathrm{E}$ to $71.4^{\circ} \mathrm{N}-12.6^{\circ} \mathrm{E}$ for altitudes below $19 \mathrm{~km}$, which are the main focus of our study as a result of the presence of the volcanic aerosols.

Variations in solar zenith angle (SZA) along solar occultation lines of sight and associated concentration variations are likely to impact the retrieved vertical profiles near sunrise and sunset especially below $20 \mathrm{~km}$ (Newchurch et al., 1996; Ferlemann et al., 1998). Some works propose using a photochemical model to correct for this effect (e.g. Harder et al., 2000; Butz et al., 2006) depending on the considered chemical compound, the observation geometry (i.e. balloon ascent or occultation) and daytime (SZA variation). Typically, concentrations are converted to values expected at $90^{\circ}$ SZA.

In our study, the $\mathrm{NO}_{2}$ profile from the SALOMON instrument recorded on 25 August 2009 from a typical solar occultation at constant float altitude is not photochemically corrected since conversion to $90^{\circ} \mathrm{SZA}$ conditions results in differences of less than $6 \%$, in agreement with the work of Payan et al. (1999). The $\mathrm{NO}_{2}$ vertical profile observed by the DOAS instrument was recorded on 7 September 2009 with a different observation geometry, i.e. during the balloon ascent. In this case applying a photochemical correction gives differences of $24 \%$ and the model-measurement comparison is done for $\mathrm{SZA}=90^{\circ}$.

Photochemical effects on the $\mathrm{BrO}$ profile obtained by the SALOMON instrument from solar occultation measurements are estimated to be $10 \%$ and are taken into account in the error estimation in accordance with the study of Ferlemann et al. (1998). Photochemical changes in the BrO slant column densities (SCDs) recorded during the balloon ascent are small, and the DOAS BrO profile has not been corrected to $90^{\circ}$ SZA (Ferlemann et al., 1998; Harder et al., 2000; Dorf et al., 2006b).

\subsection{Model calculations}

The REPROBUS (Reactive Processes Ruling the Ozone Budget in the Stratosphere) 3-D CTM has been used in a number of studies of stratospheric chemistry involving nitrogen and halogen compounds in particular through comparisons with space-borne and balloon-borne observations (e.g. Krecl et al., 2006; Berthet et al., 2005; Brohede et al., 2007). It is designed to perform annual simulations as well as detailed process studies. A description of the model is given in Lefèvre et al. (1994) and Lefèvre et al. (1998), as well as in the Appendix.

In this study, REPROBUS was integrated from 1 October 2008 to 1 October 2009 with a horizontal resolution of $2^{\circ}$ latitude by $2^{\circ}$ longitude. The ozone field was initialized on 1 April 2009 from the ECMWF ozone analysis. Following the work of Legras et al. (2005), REPROBUS has been driven by 3-hourly ECMWF wind fields obtained by interleaving operational analysis and forecasts. Using these more time-resolved and less noisy ECMWF wind fields reduced the ascent velocities of the upward branch of the BrewerDobson circulation in the tropics and largely reduced the model-measurement discrepancies by increasing the simulated global $\mathrm{NO}_{y}$ and $\mathrm{NO}_{x}$ amounts from increased $\mathrm{N}_{2} \mathrm{O}$ photo-oxidation (Berthet et al., 2006). In this configuration, the summer 2009 REPROBUS simulations are in agreement with the SPIRALE in situ observations (Fig. 1a).

As sulfur chemistry is not included in REPROBUS, we have conducted a simulation (hereafter called Ref-sim) constrained with typical background aerosol levels inferred from $\mathrm{H}_{2} \mathrm{SO}_{4}$ mixing ratios provided by the UPMC (Université Pierre et Marie Curie) 2-D model (Bekki and Pyle, 1994) and used as a reference, i.e. without volcanic aerosols. A simulation (hereafter called Sat-sim) has been set up by prescribing time-dependent variations in the stratospheric sulfate aerosol content from $1 \mathrm{~km}$ vertical resolution extinction measurements by the Optical Spectrograph and Infrared Imaging System (OSIRIS) instrument onboard the Odin satellite. OSIRIS aerosol extinction data used in this study are the validated version 5 retrieved at $750 \mathrm{~nm}$ (Bourassa et al., 2012). They compare well with the profiles inferred from the STAC 

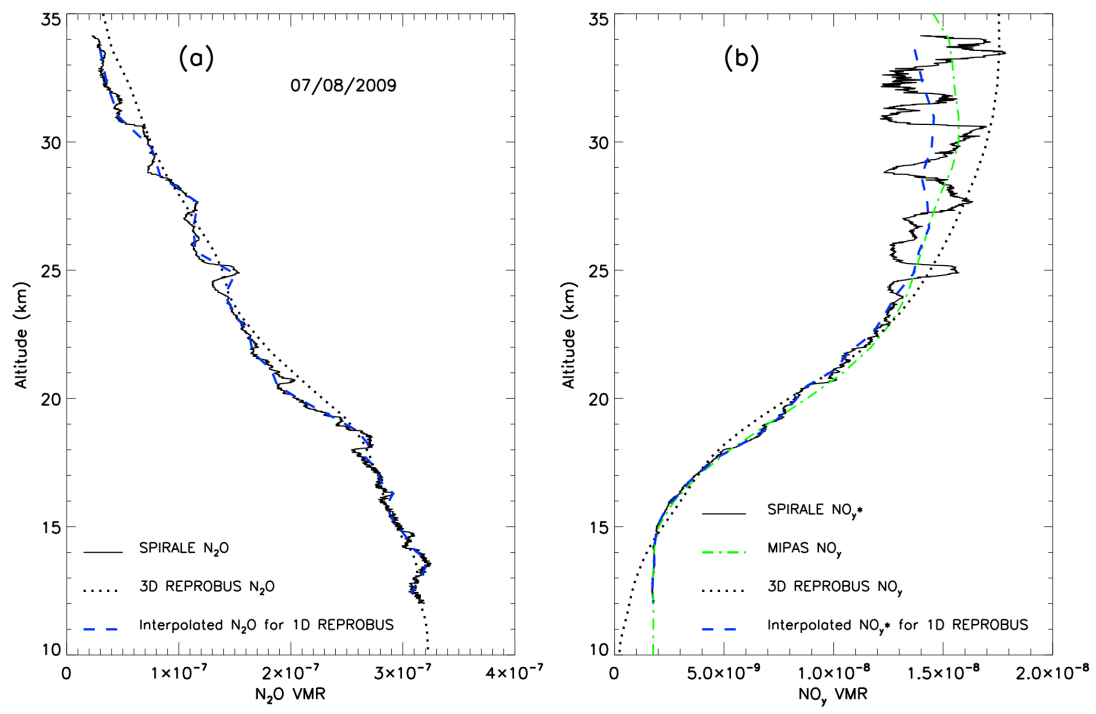

Figure 1. (a) Vertical profile of $\mathrm{N}_{2} \mathrm{O}$ recorded on 7 August 2009 (black line) compared to the results from the 3-D version of REPROBUS (dotted line). (b) Vertical profile of $\mathrm{NO}_{y}$ inferred from the SPIRALE $\mathrm{N}_{2} \mathrm{O}$ profile converted using the $\mathrm{N}_{2} \mathrm{O}-\mathrm{NO}_{y}$ correlation curve presented in Fig. 7 (referred to as $\mathrm{NO}_{y}^{*}$ ). Also shown are the $\mathrm{NO}_{y}$ profiles from the 3-D version of REPROBUS (dotted line) and the MIPAS averaged data (green line). The 1-D version of REPROBUS is computed with the profiles interpolated to the model resolution (blue lines).

balloon-borne aerosol counter (Jégou et al., 2013), thus providing confidence in the use of the data as a basis for considering time-dependent changes in aerosol content. OSIRIS data were averaged daily and zonally over $10^{\circ}$ latitude bins. A standard Mie scattering model (Van de Hulst, 1957; Wiscombe, 1980; Steele and Turco, 1997) has been run to convert extinction values to $\mathrm{H}_{2} \mathrm{SO}_{4}$ mixing ratios from parameters of log-normal unimodal size distributions provided by the STAC instrument and used in the work of Jégou et al. (2013) in the Sarychev aerosol conditions. The derived $\mathrm{H}_{2} \mathrm{SO}_{4}$ mixing ratios have then been incorporated into the model over the period of the presence of the Sarychev aerosols in the Northern Hemisphere lower stratosphere, i.e. from the beginning of July 2009 onwards. The simulation has been conducted until October 2009 because OSIRIS data at high latitudes are lacking beyond this period due to decreasing solar illumination.

We have conducted another type of simulation (hereafter called Bal-sim) consisting in adjusting the input $\mathrm{H}_{2} \mathrm{SO}_{4}$ mixing ratios so that the model output matches SADs observed by the STAC aerosol counter. Although similar aerosol SAD values were observed by Kravitz et al. (2011) in November 2009 , i.e. $\sim 2$ months after the STAC measurements as mentioned by Jégou et al. (2013), a single vertical profile may be not representative of the geographical distribution of the still unmixed volcanic plume throughout summer 2009. To account for the range of aerosol variability as observed by STAC over the Arctic region for the August-September period (Fig. 2), we have performed two simulations based on the spread ( $1 \sigma$ standard deviation) of observed SADs. We have excluded data suspected to be spoilt by balloon out- gassing as deduced from joint water vapour measurements. Also, flights revealing the sporadic presence of clouds are not considered to derive the range of SADs below $12 \mathrm{~km}$. Each Bal-sim simulation is driven by the lower and the upper bound of observed SAD values below $20 \mathrm{~km}$ (Fig. 2) from the beginning of August until the end of the model run for latitudes above $40^{\circ} \mathrm{N}$. Note that in Bal-sim, $\mathrm{H}_{2} \mathrm{SO}_{4}$ mixing ratios in July are taken from the Sat-sim simulation.

\section{Impact of the volcanic aerosols on stratospheric nitrogen compounds: comparisons between balloon-borne observations and model simulations}

\subsection{Photochemical conditions}

$\mathrm{N}_{2} \mathrm{O}_{5}$ is produced mainly at night from the recombination of $\mathrm{NO}_{2}$ with $\mathrm{NO}_{3}$ and destroyed during the day by photolysis leading to the reformation of $\mathrm{NO}_{2}$. Polar summer is characterized by continuous solar illumination preventing the formation of $\mathrm{N}_{2} \mathrm{O}_{5}$ (Fahey and Ravishankara, 1999) until about the beginning of August (Brühl et al., 1998), i.e. around day 213 for the considered Esrange/Kiruna location as illustrated in Fig. 3 at $17.5 \mathrm{~km}$. When $\mathrm{NO}_{3}$ reforms at this time, significant conversion of $\mathrm{NO}_{2}$ to $\mathrm{N}_{2} \mathrm{O}_{5}$ occurs during the night. The associated decrease in $\mathrm{NO}_{x}$ is reflected in Fig. 3. The conversion of $\mathrm{N}_{2} \mathrm{O}_{5}$ to $\mathrm{HNO}_{3}$ through Reaction (R1) occurs almost exclusively at night. As the season progresses, the increase in the conversion rate caused by the increase in night duration is moderated by the decrease in $\mathrm{NO}_{2}$ amounts at the beginning of the night. 


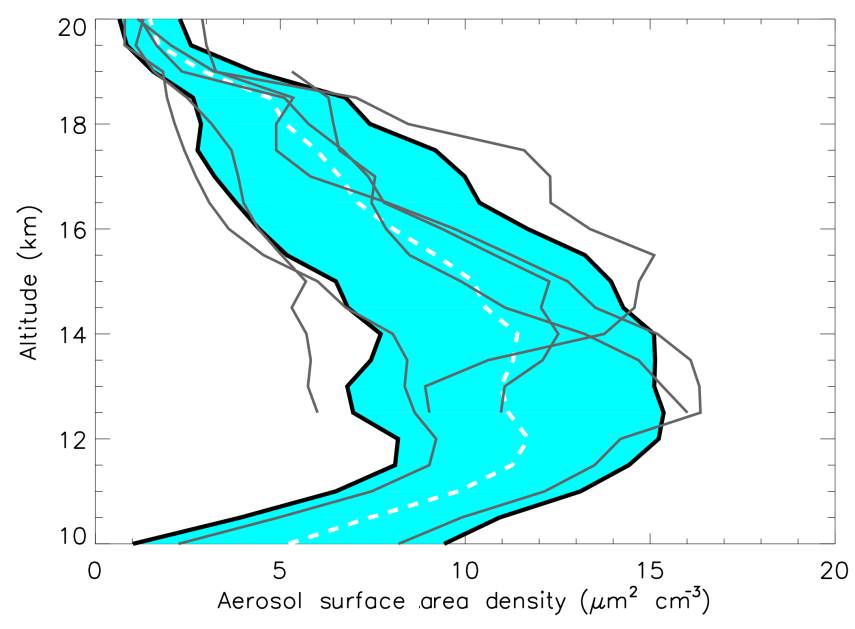

Figure 2. Range of aerosol SAD values (black lines) as derived from several balloon-borne observations in the lower stratosphere in summer 2009 ( $1 \sigma$ standard deviation of the mean). The individual profiles (grey lines) and their average (white dashed line) are also presented. Data supposed to be spoilt by balloon outgassing as revealed from simultaneous in situ water vapour observations and data revealing the sporadic presence of clouds below $12 \mathrm{~km}$ have been excluded.

As expected, increasing $\mathrm{SAD}$ values in the model to reproduce the volcanic aerosol levels has no effect on $\mathrm{N}_{2} \mathrm{O}_{5}$ (and on the production of $\mathrm{HNO}_{3}$ ) and on $\mathrm{NO}_{x}$ during the period of continuous solar illumination. However, from the onset of $\mathrm{N}_{2} \mathrm{O}_{5}$ recovery, a significant decrease in the $\mathrm{N}_{2} \mathrm{O}_{5}$ and $\mathrm{NO}_{x}$ levels in comparison with the background aerosol simulation is calculated as the lifetime of $\mathrm{N}_{2} \mathrm{O}_{5}$ in Reaction (R1) is reduced (e.g. Kinnison et al., 1994) and as further nitrogen oxides are converted to the more stable $\mathrm{HNO}_{3}$ reservoir.

This situation implies that the balloon flights performed from 7 August 2009 in the Kiruna region match the photochemical conditions for which volcanic aerosols likely have an impact on $\mathrm{NO}_{y}$ partitioning via elevated $\mathrm{N}_{2} \mathrm{O}_{5}$ hydrolysis and can be suitably used to investigate heterogeneous processes.

\section{$3.2 \quad \mathrm{NO}_{2}$}

\subsubsection{Model comparisons with observations}

For the Sarychev situation, minima in $\mathrm{NO}_{2}$ concentrations appear closely correlated with enhancements in aerosol amounts in the lower stratosphere (Fig. 4). Thus the empirical evidence supports the view that $\mathrm{NO}_{x}$ chemistry is largely driven by heterogeneous processes even in the case of a moderate volcanic eruption. The vertical structures depicted in Fig. 4 confirm that the plume is not homogeneously mixed over the Arctic region $\sim 2$ months after the eruption. Minimum concentration values of 1 to 2 particles $\mathrm{cm}^{-3}$ (for sizes $>0.4 \mu \mathrm{m}$ ) correspond to unperturbed background extra-

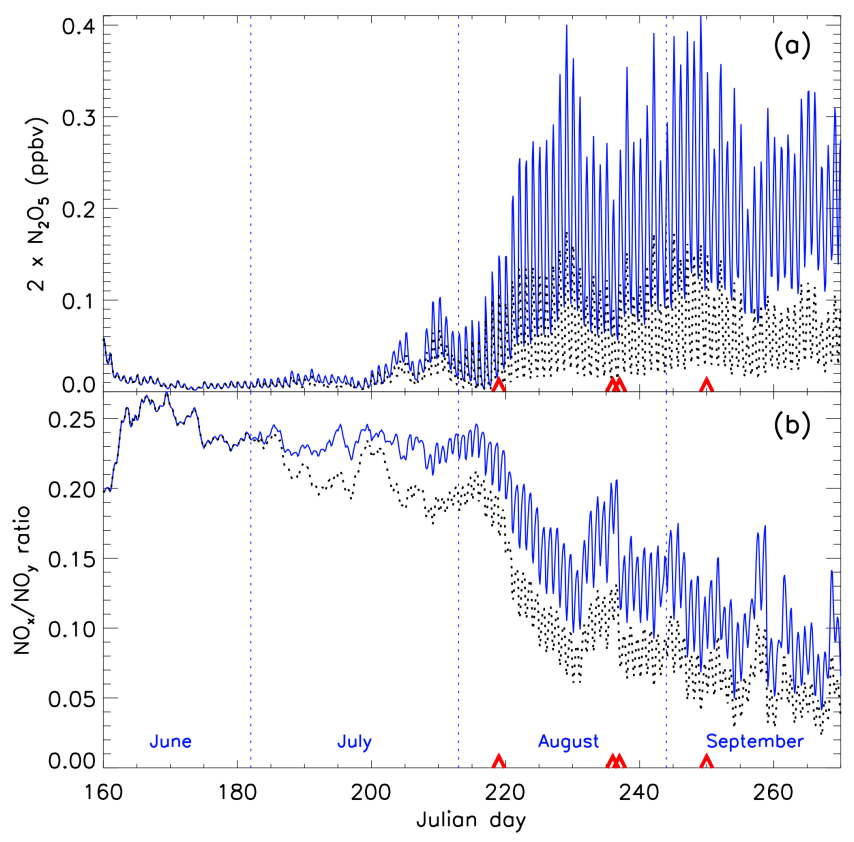

Figure 3. Seasonal variation in $\mathrm{N}_{2} \mathrm{O}_{5}$ (a) and in the $\mathrm{NO}_{x} / \mathrm{NO}_{y}$ ratio (b) simulated by the REPROBUS CTM above Kiruna in northern Sweden $\left(67.5^{\circ} \mathrm{N}, 21.0^{\circ} \mathrm{E}\right)$ around $17.5 \mathrm{~km}$. The simulation driven by non-volcanic aerosol contents (Ref-sim) is shown in blue. The black dotted line is the REPROBUS simulation driven by volcanic aerosol levels from STAC balloon-borne observations (Balsim). Red triangles represent the dates of the balloon flights. $\mathrm{N}_{2} \mathrm{O}_{5}$ recovery onset is at the beginning of August (day 213 is $1 \mathrm{Au}-$ gust 2009), i.e. when SZA become $>90^{\circ}$.

vortex conditions (Renard et al., 2010) and therefore indicate air masses unaffected by the volcanic aerosols. Conversely, layers with aerosol concentration increases by more than a factor of 3 (with respect to the mean profiles) can be assigned to the presence of the volcanic plume and show associated reductions in $\mathrm{NO}_{2}$ by up to a factor of $\sim 2$.

Figures 5 and 6 present the measured profiles of $\mathrm{NO}_{2}$ obtained by the SPIRALE, SALOMON and DOAS instruments, together with REPROBUS model outputs for altitudes below $20 \mathrm{~km}$ where the Sarychev aerosols were present. In contrast to the reference simulations, the Bal-sim simulations constrained by the range of aerosol SADs observed by STAC show significant improvement in comparison with the non-volcanic calculations with, for instance, average differences of $3 \pm 20 \%$ for SPIRALE-07082009. Results from the Sat-sim simulations driven by OSIRIS satellite data are very close to the Bal-sim results and are only shown for the SPIRALE flights.

It may be noted that the REPROBUS calculations do not reproduce some of the vertical structures detected by the SPIRALE instrument, i.e. between 17.5 and $19.5 \mathrm{~km}$ for SPIRALE-07082009 and at 17 and $20.5 \mathrm{~km}$ for SPIRALE24082009. This is likely due to the vertical resolution of the model or inaccurate simulation of mixing effects in the CTM 


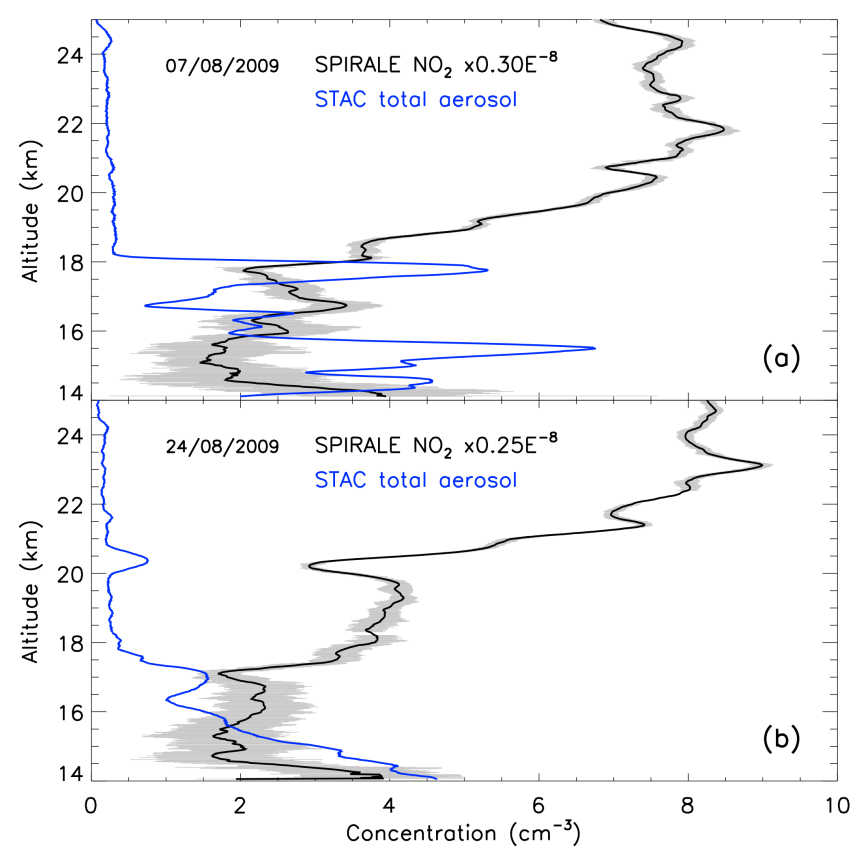

Figure 4. Vertical profiles of $\mathrm{NO}_{2}$ observed by the SPIRALE balloon-borne instrument (black line with grey shaded error bars) on 7 August 2009 (a) and 24 August 2009 (b) compared to the total aerosol concentration profiles (for sizes $>0.4 \mu \mathrm{m}$ ) simultaneously recorded by the STAC aerosol counter (blue line) above Kiruna during the balloon ascent. SPIRALE data have been averaged over $250 \mathrm{~m}$ (corresponding to $\sim 1 \mathrm{~min}$ of measurements).

as already mentioned in previous studies showing this kind of comparison (e.g. Berthet et al., 2006).

Calculated differences between the reference and the volcanic-aerosol-constrained simulations provide an estimation of the chemical perturbation induced by the Sarychev aerosols. Reductions in $\mathrm{NO}_{2}$ mixing ratios between 34 and $50 \%$ are simulated on average below $19 \mathrm{~km}$. For a stratosphere affected by the Pinatubo aerosols, decreases ranging from 30 to $45 \%$ have been reported both in model calculations of $\mathrm{NO}_{2}$ concentrations (Kinnison et al., 1994; Webster et al., 1994) and in the $\mathrm{NO}_{2}$ columns (Johnston et al., 1992; Koike et al., 1993, 1994; Solomon et al., 1994). At a glance, the amplitude in the $\mathrm{NO}_{2}$ reduction is therefore similar for both eruptions, but it should be noted that results from these above-mentioned studies were provided for different latitudes, various seasons and correspond to wider altitude ranges as a result of the larger vertical extent of the Pinatubo aerosol cloud.

\subsubsection{One-dimensional model calculations}

Some small model-measurement discrepancies in the 20$35 \mathrm{~km}$ altitude range as shown in the embedded plots in Figs. 5 and 6 suggest that the model-measurement differences in the lower stratosphere may be only partly attributed to remaining uncertainties in calculations of transport. A way to discard a possible remaining effect of transport and improve the modelling of total $\mathrm{NO}_{y}$ is to use one-dimensional (1-D) calculations constrained by observations (Dufour et al., 2005; Berthet et al., 2006).

Total $\mathrm{NO}_{y}$ from SPIRALE measurements can be derived from established $\mathrm{N}_{2} \mathrm{O}-\mathrm{NO}_{y}$ correlation curves. Since the study of Michelsen et al. (1998), global emissions of $\mathrm{N}_{2} \mathrm{O}$ have increased and the $\mathrm{N}_{2} \mathrm{O}-\mathrm{NO}_{y}$ correlations reported therein need some revision. As a consequence, we have constructed updated correlation curves from the Institute for Meteorology and Climate Research/Instituto de Astrofísica de Andalucía (IMK/IAA) V5R_220 MIPAS-Envisat data for the high latitude in summer stratosphere (Fischer et al., 2008; data available at http://www.imk-asf.kit.edu/english/ 308.php) as shown in Fig. 7 in which the Michelsen et al.'s (1998) previous results are also represented for comparison. An example of the estimated vertical profile of $\mathrm{NO}_{y}$ (hereafter $\mathrm{NO}_{y}^{*}$ ) derived from the conversion of the SPIRALE $\mathrm{N}_{2} \mathrm{O}$ profile (Fig. 1a) using the $\mathrm{N}_{2} \mathrm{O} / \mathrm{NO}_{y}$ ratios derived from MIPAS data is presented in Fig. 1b. Then, following the strategy of Berthet et al. (2006) the $\mathrm{N}_{2} \mathrm{O}$ and the derived $\mathrm{NO}_{y}^{*}$ profiles for SPIRALE-07082009 and SPIRALE24082009 are used to initialize the REPROBUS 1-D version.

The 1-D-REPROBUS reference simulation is computed with background aerosol levels, whereas the Sarychev aerosol-affected simulation is constrained with the mean observed aerosol profile presented in Fig. 2. As a result of the $\mathrm{NO}_{y}^{*}$ input in the calculations, the 1-D reference simulations show very good agreement for $\mathrm{NO}_{2}$ (in red in Fig. 5) with the SPIRALE measurements above $20 \mathrm{~km}$. The 1-D simulations constrained by observed volcanic aerosol quantities (in yellow in Fig. 5) match well with the in situ measurements. The calculated chemical impact on $\mathrm{NO}_{2}$ clearly gives percentage values similar to the 3-D simulation results because both $\mathrm{NO}_{y}^{*}$ and 3-D NO$y$ profiles agree well in the lower stratosphere (Fig. 1b). We note that fine structures in the measured profile are not reproduced by the 1-D model as a matter of height resolution and interpolation (Berthet et al., 2006).

Overall the 1-D $\mathrm{NO}_{y}$-constrained simulations do not significantly improve the comparisons. This result confirms that the model-observation differences in the lower stratosphere can be mostly attributed to heterogeneous processes and not to spurious calculations of transport.

\subsubsection{Saturation effect of $\mathrm{NO}_{x}$ reduction}

The reduction of $\mathrm{NO}_{x}$ from the results described above (Sect. 3.2.1) is significant but also indicates some saturation through Reaction (R1) for the range of SADs observed for the Sarychev aerosols. The partitioning between $\mathrm{NO}_{x}$ and $\mathrm{NO}_{y}$ is expected to become insensitive to increases in aerosol SAD beyond a certain value when $\mathrm{N}_{2} \mathrm{O}_{5}$ hydrolysis is the dominant sink for $\mathrm{NO}_{x}$ because the night-time formation of $\mathrm{N}_{2} \mathrm{O}_{5}$ by reaction of $\mathrm{NO}_{2}$ and $\mathrm{NO}_{3}$ is quadratically dependent on $\mathrm{NO}_{x}$. This effect is reflected in Fig. 8 


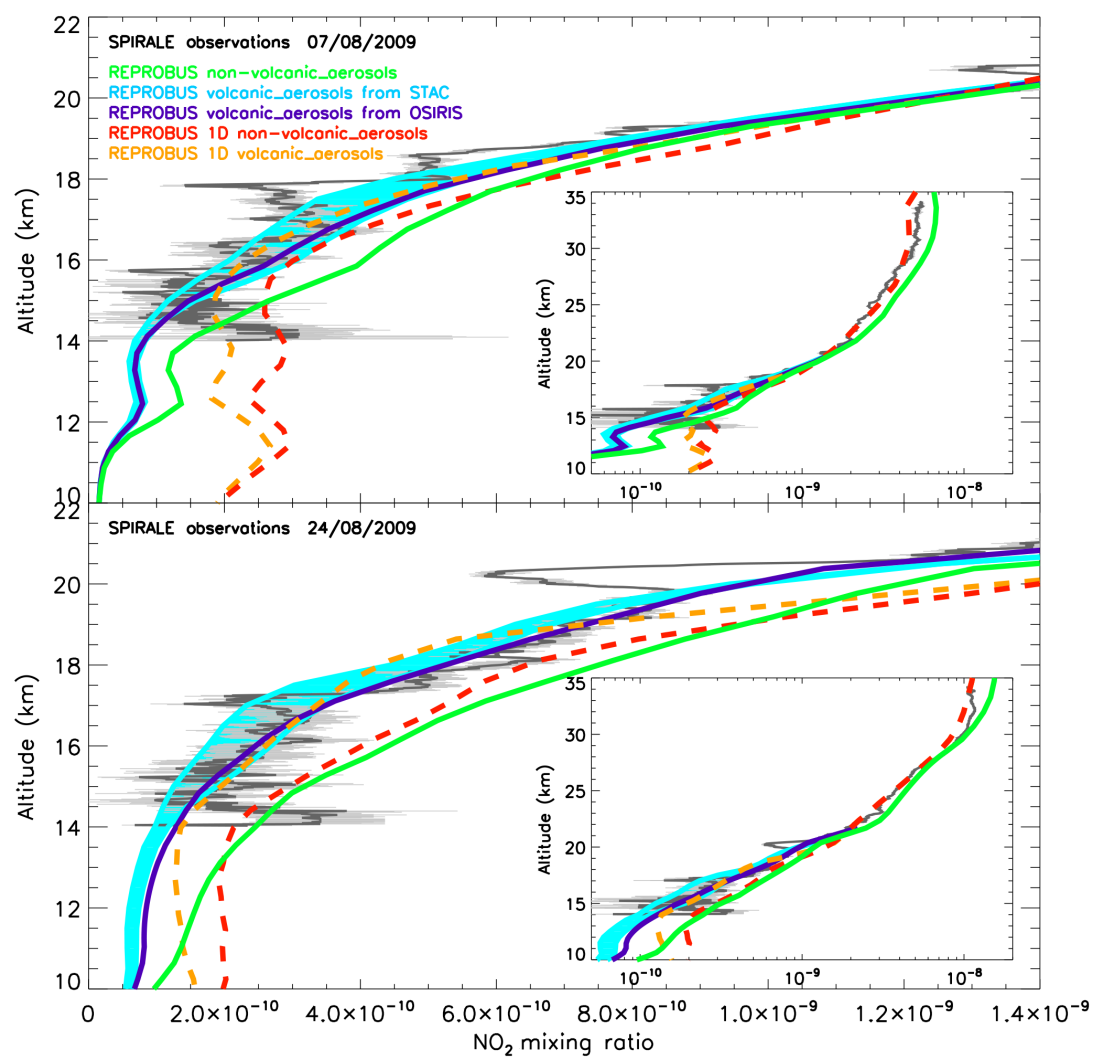

Figure 5. Vertical profile of $\mathrm{NO}_{2}$ observed by the SPIRALE balloon-borne instrument (black line) above Kiruna during the balloon ascent between 02:00 and 02:30 UT ( $\sim 87^{\circ}$ SZA at 02:15 UT) for the 7 August 2009 flight (top) and between 21:00 and 21:30 UT ( $\sim 100^{\circ}$ SZA at 21:15 UT) for the 24 August 2009 flight (bottom). Model outputs (available every 15 min) are provided for the closest location of the instrument and interpolated to the time of observations. Three-dimensional simulations were driven without volcanic aerosols (green), with volcanic aerosols from balloon-borne observations (blue shaded area) and with volcanic aerosols from satellite data (dark blue line). Results from a one-dimensional (1-D) version of the REPROBUS model (dashed lines) computed using hybrid $\mathrm{NO}_{y}$ profiles $\left(\mathrm{NO}_{y}^{*}\right)$ derived from the observed profiles of $\mathrm{N}_{2} \mathrm{O}$ are also provided (see text), with the non-volcanic reference simulations in red and the calculations driven with volcanic aerosols from the mean observed balloon-borne profile presented in Fig. 2 in yellow.

presenting the $\mathrm{NO}_{2}-\mathrm{SAD}$ curve constructed for the range of altitudes spanned by the volcanic plume (i.e. with different $\mathrm{NO}_{y}$ amounts and photochemistry). Although the asymptotic behaviour in the $\mathrm{NO}_{2}$ reduction would be more evident if shown for a given altitude level with constant SZA and varying SADs, our results indicate saturation for SAD values larger than about $4 \mu \mathrm{m}^{-1} \mathrm{~cm}^{-3}$, which is reached on average for altitudes around $18 \mathrm{~km}$. The net reduction of $\mathrm{NO}_{x}$ reported for the Pinatubo aerosols tends to saturate at similar SADs in the 18-22 km range, as shown in the works of Fahey et al. (1993), Kondo et al. (1997) and Sen et al. (1998).

\section{3 $\mathrm{HNO}_{3}$ and $\mathrm{NO}_{2} / \mathrm{HNO}_{3}$ ratio}

We consider here total $\mathrm{HNO}_{3}$, i.e. both in the gas phase and condensed. All the REPROBUS-simulated profiles for $\mathrm{HNO}_{3}$ are mostly within the errors bars of the SPIRALE measurements and only differ by less than $10 \%$ on average (not shown). Calculated amounts from Bal-sim are increased by $10-13 \%$ when including volcanic aerosols below $19 \mathrm{~km}$, highlighting limited effects on $\mathrm{HNO}_{3}$.

The $\mathrm{NO}_{2} / \mathrm{HNO}_{3}$ ratio can be used as a good approximation of the $\mathrm{NO}_{x} / \mathrm{NO}_{y}$ ratio to reduce the uncertainty in a model estimate of $\mathrm{NO}_{y}$ (e.g. Webster et al., 1994; Berthet et al., 2006). This is especially useful for the SPIRALE flights for which modelled $\mathrm{NO}_{2}$ and $\mathrm{HNO}_{3}$ amounts account for more than $92 \%$ of total $\mathrm{NO}_{y}$. Good agreement is obtained between the observed $\mathrm{NO}_{2} / \mathrm{HNO}_{3}$ ratio and the model outputs by including the Sarychev aerosols, with, for instance, absolute differences decreasing to $3 \pm 20 \%$ for the Bal-sim simulation for SPIRALE-07082009 (Fig. 9). However, no clear improvement is noticed with respect to the modelmeasurement comparisons presented in Fig. 5 for $\mathrm{NO}_{2}$ both at and above the altitudes of the plume. One-dimensional calculations do not show improvement either (not shown). Again this indicates that transport calculation is not a major issue in the comparisons. Reductions in the $\mathrm{NO}_{2} / \mathrm{HNO}_{3}$ ratios between 36 and $44 \%$ are simulated on average below 


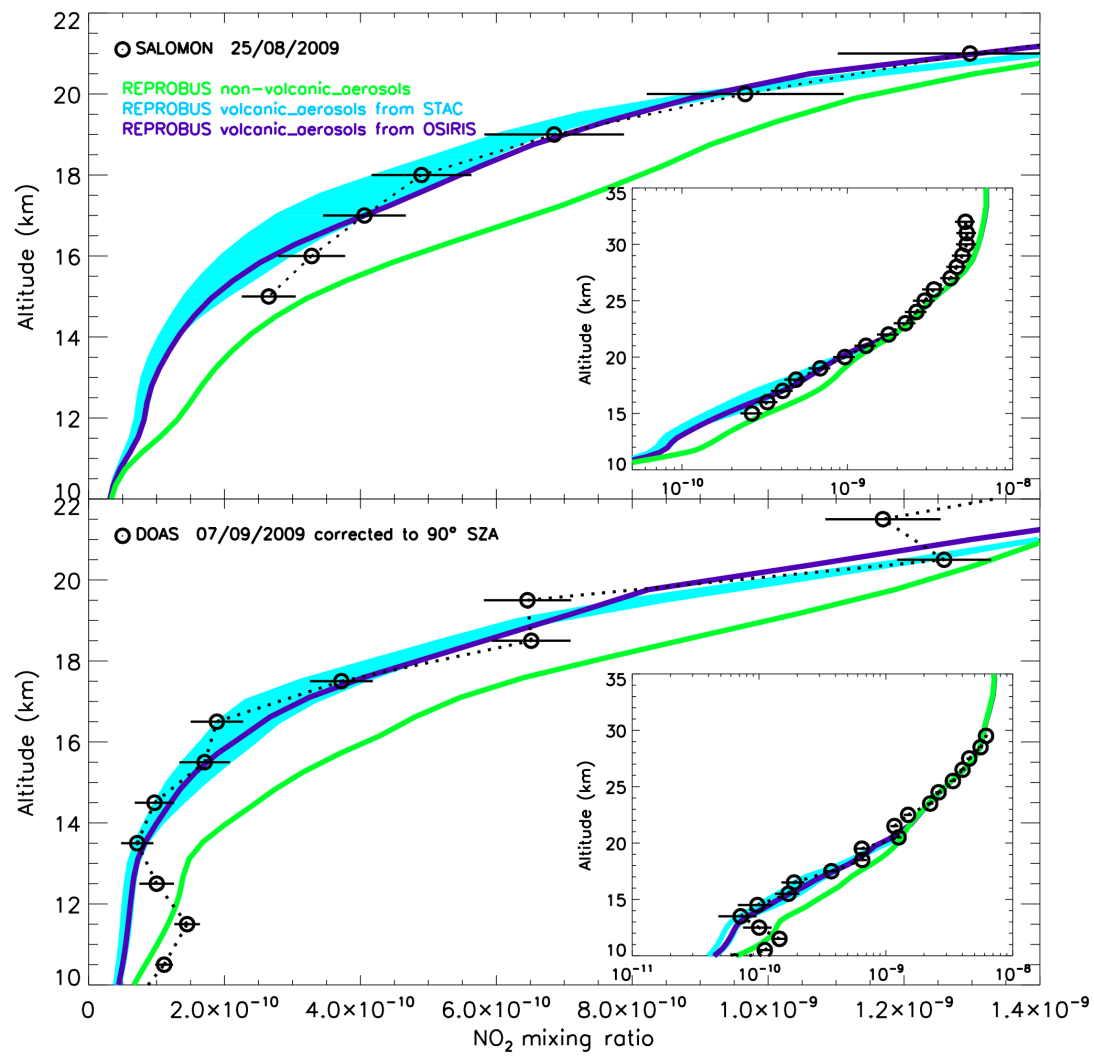

Figure 6. Top: vertical profile of $\mathrm{NO}_{2}$ recorded by the SALOMON instrument (black lines) obtained during solar occultation between 18:50 (32 km tangent height) and 19:30 UT (15 km tangent height) on 25 August 2009 above Kiruna. Chemistry-transport model simulations computed with no volcanic aerosols (green line), with volcanic aerosols from balloon-borne observations (blue shaded area) and with volcanic aerosols from satellite data (dark blue line) are shown. The model output is provided for the closest location of the tangent points. Bottom: vertical profile of $\mathrm{NO}_{2}$ recorded by the DOAS instrument (black lines) on 7 September 2009 above Kiruna. The DOAS profile was recorded during the balloon ascent and has been converted to $90^{\circ}$ SZA $(\sim 17: 30$ UT $)$ as well as the simulated profile.

$19 \mathrm{~km}$ for SPIRALE-07082009 and SPIRALE-24082009 respectively when volcanic aerosols are included.

For the Pinatubo-aerosol-loaded stratosphere, maximum $\mathrm{HNO}_{3}$ column increases of $30-40 \%$ have been measured at midlatitudes (e.g. Koike et al., 1994). Reductions ranging from 20 to $45 \%$ have been reported both in the observed $\mathrm{NO}_{2} / \mathrm{HNO}_{3}$ column ratios (Koike et al., 1994) and in model calculations (Webster et al., 1994). However, quantifying the difference between both eruptions through comparisons of local concentrations versus columns remains challenging because the production efficiency of $\mathrm{HNO}_{3}$ by heterogeneous processes generally depends on the altitude level where volcanic aerosols are present (Webster et al., 1994; Danilin et al., 1999). In particular, the observed signature of the Pinatubo-induced $\mathrm{HNO}_{3}$ enhancement was not limited to the lower stratosphere and prevailed above the 420-465 K ( 16-18 km) vertical range (Webster et al., 1994; Santee et al., 2004).
4 Impact of the volcanic aerosols on the coupled catalytic cycles involving halogen, nitrogen and $\mathrm{HO}_{x}$ compounds

\subsection{Chlorine partitioning}

Several studies have revealed the impact of the Pinatubo eruption on the stratospheric halogen chemistry. This has been shown to be of particular importance regarding ozone destruction processes through the partitioning of chlorine reservoir species and the activation of chlorine radicals on volcanic aerosols (e.g. Solomon, 1999, and references therein).

Some volcanic eruptions are likely to inject halogenated compounds within the stratosphere, therefore impacting directly the halogen content and bypassing (or adding to) in situ heterogeneous processes. For the Sarychev volcano eruption, an injection of several ppbv of $\mathrm{HCl}$ into the stratosphere has been reported by Carn et al. (2016) using Microwave Limb Sounder (MLS) data, mainly below the $140 \mathrm{hPa}$ level (see their Fig. 4). However, because of the low vertical resolution 


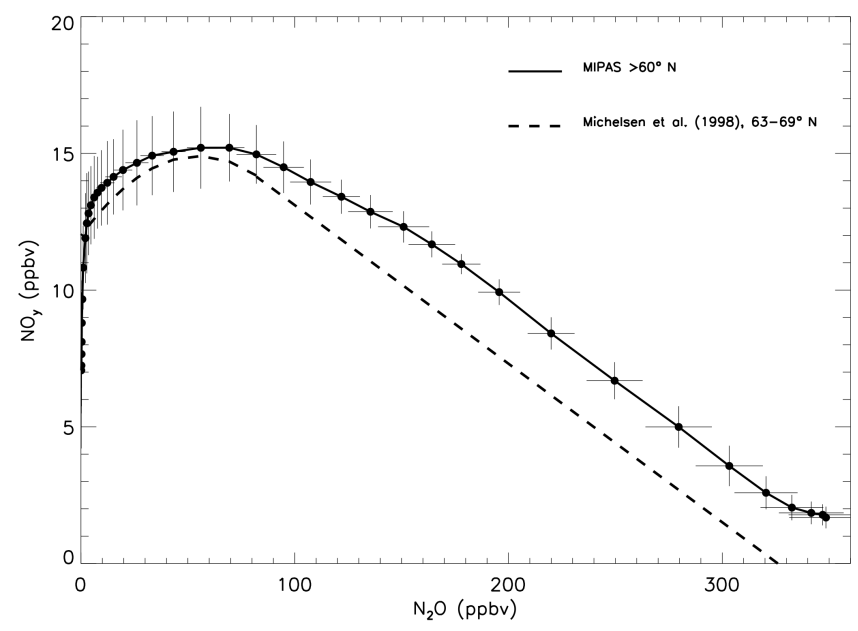

Figure 7. $\mathrm{N}_{2} \mathrm{O}-\mathrm{NO}_{y}$ correlation curve inferred from IMK/IAA V5R_220 MIPAS-Envisat data at high latitudes $\left(>60^{\circ} \mathrm{N}\right)$ in JulyAugust 2009 (full line). Error bars reflect the spread of the data. The former Michelsen et al. (1998) correlation is also shown for comparison (dashed line).

of MLS data, i.e. $\sim 3 \mathrm{~km}$, the exact altitude of injection is unclear and requires further investigation. In addition, MLS $\mathrm{HCl}$ measurements are known to be biased high below the $100 \mathrm{hPa}$ level (Livesey et al., 2011), making it difficult to infer a robust injection amount. As a consequence, the possible effect of the $\mathrm{HCl}$ injection on the stratospheric chlorine chemistry is not investigated in our study.

We therefore examine the direct impact of the Sarychev sulfate aerosols on the chlorine partitioning in connection with $\mathrm{NO}_{x}$ and $\mathrm{HO}_{x}$ in the lower stratosphere. Heterogeneous reactions on volcanic aerosols involving the $\mathrm{ClONO}_{2}$ and $\mathrm{HCl}$ chlorine reservoirs (especially Reaction R2) have been shown to play a major role in determining the abundance of active chlorine and therefore they are likely to compete with Reaction (R1) as a sink of $\mathrm{NO}_{x}$ depending on ambient temperature values (e.g. Hanson et al., 1994). Significant decreases in $\mathrm{HCl}$ and corresponding increases in $\mathrm{ClONO}_{2}$ have been reported for temperatures below $210 \mathrm{~K}$ in the lower stratosphere, with a strong temperature sensitivity when volcanic aerosol amounts are large (Michelsen et al., 1999; Webster et al., 1998, 2000). Table 1 presents the calculated effects of the Sarychev aerosols on the partitioning of the halogen species at $16.5 \mathrm{~km}$. Simulated levels of $\mathrm{HCl}$ decrease by $3 \%$ ( $\sim 20 \mathrm{pptv}$ ), which is much smaller than the change observed by Webster et al. (2000) for the Pinatubo aerosols (about $-31 \%$ at $21 \mathrm{~km}$ ). Higher levels of $\mathrm{ClONO}_{2}$ are simulated post the Sarychev eruption with respect to background conditions with increases of about $16 \%(\sim 20 \mathrm{pptv})$. $\mathrm{ClO}$ and $\mathrm{HOCl}$ increase by $106 \%$ ( 6 pptv) and $217 \%(\sim 2 \mathrm{pptv})$ respectively during the daytime. It is interesting to note that these results for $\mathrm{ClO}$ are comparable to the calculations of Tie et al. (1994), who show $\mathrm{ClO}$ increases by at least $5 \mathrm{pptv}$

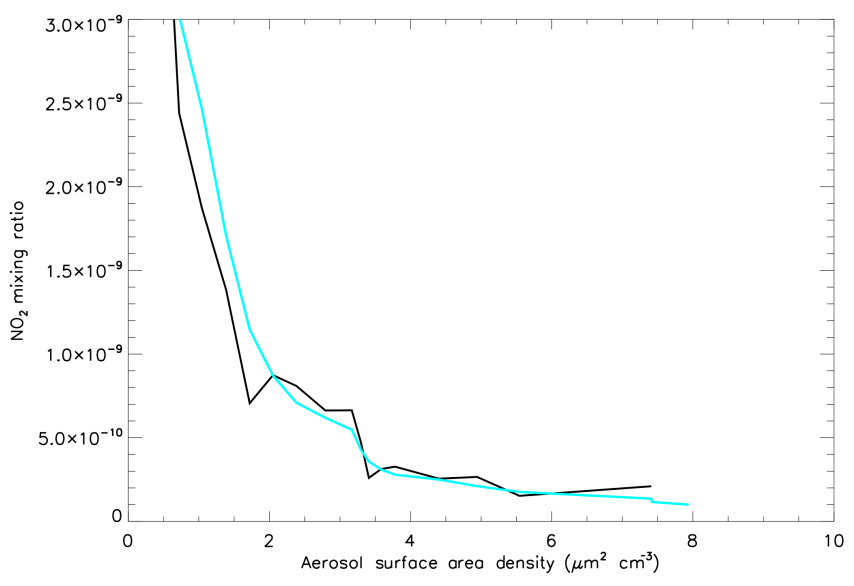

Figure 8. $\mathrm{NO}_{2}$ mixing ratio as a function of aerosol SAD as simultaneously observed in the lower stratosphere by the SPIRALE and STAC instruments on 24 August 2009 (black curve). The result of the REPROBUS Bal-sim simulation is also plotted (blue curve).

in the lower stratosphere for summer 1992 at a time when Pinatubo-related aerosol SADs were similar to August 2009 values.

The impact of the volcanic aerosols on the chlorine partitioning appears somewhat small since it is primarily the consequence of the increasing losses of $\mathrm{HCl}$ by enhanced $\mathrm{OH}$ through reaction $\mathrm{HCl}+\mathrm{OH} \rightarrow \mathrm{Cl}+\mathrm{H}_{2} \mathrm{O}$ (McElroy et al., 1992; Webster et al., 2000) rather than by Reaction (R2), for which the efficiency is low in the $\sim 215-225 \mathrm{~K}$ range of temperatures mostly encountered in the lower stratosphere over the August-September 2009 period (see Fig. 9 in Jégou et al., 2013). In fact, in the model $\mathrm{HO}_{x}$ is increased by $51 \%(\sim 1.4 \mathrm{pptv})$ (Table 1$)$, and destruction of $\mathrm{HCl}$ by $\mathrm{OH}$ is faster than the $\mathrm{HCl}$ formation reaction $\mathrm{Cl}+\mathrm{CH}_{4} \rightarrow \mathrm{HCl}+\mathrm{CH}_{3}$. An additional source of $\mathrm{OH}$ is due to the photolysis of $\mathrm{HNO}_{3}$ (Rodriguez et al., 1991; Webster et al., 2000). Also, the decreased reaction rate of reaction $\mathrm{NO}_{2}+\mathrm{OH}+\mathrm{M} \rightarrow \mathrm{HNO}_{3}+\mathrm{M}$ in reduced $\mathrm{NO}_{x}$ conditions (Kinnison et al., 1994) may increase OH. As also described by Bekki and Pyle (1994), subsequent production of reactive chlorine and increase in $\mathrm{ClO}$ is accompanied by an increase in $\mathrm{ClONO}_{2}$ amounts through an increased rate of reaction $\mathrm{ClO}+\mathrm{NO}_{2}+\mathrm{M} \rightarrow \mathrm{ClONO}_{2}+\mathrm{M}$, for which $\mathrm{ClO}$ is the limiting reactant. To a lesser extent, a decreased rate of Reaction (R3) for the observed temperature range contributes to this increase. Overall, the $\mathrm{ClONO}_{2}$ increase compensates for the $\mathrm{HCl}$ decrease in Reaction (R3) (Kinnison et al., 1994; Michelsen et al., 1999; Webster et al., 2000). HOCl amounts rise as a result of slightly enhanced $\mathrm{ClONO}_{2}$ hydrolysis and production by enhanced $\mathrm{HO}_{x}$ through reaction $\mathrm{HO}_{2}+\mathrm{ClO} \rightarrow \mathrm{HOCl}+\mathrm{O}_{2}$. 
Table 1. Simulated changes on various stratospheric key species due to the Sarychev volcanic aerosols over the August-September 2009 period at $16.5 \mathrm{~km}$. Numbers are taken from the Sat-sim simulation. Effects for daytime and night-time conditions are provided depending on statistically significant amounts in the diurnal cycle of a given compound. Also, the contribution of $\mathrm{BrONO}_{2}$ hydrolysis (Reaction $\mathrm{R} 4$ ) to changes on the various species is shown (see text).

\begin{tabular}{|c|c|c|c|c|c|c|}
\hline \multirow{3}{*}{$\begin{array}{l}\text { Species } \\
\mathrm{NO}_{x}\end{array}$} & \multicolumn{4}{|c|}{ All chemistry } & \multicolumn{2}{|c|}{$\mathrm{BrONO}_{2}$ hydrolysis effect } \\
\hline & \multicolumn{2}{|c|}{$12: 00 \mathrm{UT}$} & \multicolumn{2}{|c|}{ 00:00 UT } & $12: 00 \mathrm{UT}$ & 00:00 UT \\
\hline & $-0.23 \mathrm{ppbv}$ & $-44 \%$ & $-0.19 \mathrm{ppbv}$ & $-48 \%$ & $1.8 \%$ & $1.1 \%$ \\
\hline $\mathrm{NO}_{2}$ & $-0.12 \mathrm{ppbv}$ & $-43 \%$ & $-0.19 \mathrm{ppbv}$ & $-48 \%$ & $1.8 \%$ & $1.1 \%$ \\
\hline $\mathrm{NO}$ & $-0.11 \mathrm{ppbv}$ & $-45 \%$ & - & _ & $2.0 \%$ & - \\
\hline $\mathrm{HNO}_{3}$ & $+0.31 \mathrm{ppbv}$ & $+11 \%$ & $+0.31 \mathrm{ppbv}$ & $+11 \%$ & $-2.3 \%$ & $-0.9 \%$ \\
\hline $\mathrm{N}_{2} \mathrm{O}_{5}$ & $-0.08 \mathrm{ppbv}$ & $-80 \%$ & $-0.12 \mathrm{ppbv}$ & $-66 \%$ & $-3.6 \%$ & $-3.1 \%$ \\
\hline $\mathrm{ClONO}_{2}$ & $+0.02 \mathrm{ppbv}$ & $+16 \%$ & $+0.02 \mathrm{ppbv}$ & $+22 \%$ & $66.2 \%$ & $60.6 \%$ \\
\hline $\mathrm{HCl}$ & $-0.02 \mathrm{ppbv}$ & $-3 \%$ & $-0.02 \mathrm{ppbv}$ & $-3 \%$ & $58.8 \%$ & $58.9 \%$ \\
\hline $\mathrm{ClO}_{x}$ & $+5.77 \mathrm{pptv}$ & $+106 \%$ & - & - & $39.3 \%$ & - \\
\hline $\mathrm{ClO}$ & $+5.77 \mathrm{pptv}$ & $+106 \%$ & - & - & $39.3 \%$ & - \\
\hline $\mathrm{HOCl}$ & $+2.17 \mathrm{pptv}$ & $+217 \%$ & $+1.16 \mathrm{pptv}$ & $+346 \%$ & $47.4 \%$ & $50.1 \%$ \\
\hline $\mathrm{BrONO}_{2}$ & $-1.37 \mathrm{pptv}$ & $-33 \%$ & $-4.15 \mathrm{pptv}$ & $-70 \%$ & $18.3 \%$ & $98 \%$ \\
\hline $\mathrm{BrO}$ & $+0.94 \mathrm{pptv}$ & $+22 \%$ & - & - & $16.2 \%$ & - \\
\hline $\mathrm{HOBr}$ & - & - & $+3.89 \mathrm{pptv}$ & $+141 \%$ & - & $98.8 \%$ \\
\hline $\mathrm{HO}_{x}$ & $+1.41 \mathrm{pptv}$ & $+51 \%$ & - & - & $24.1 \%$ & - \\
\hline $\mathrm{OH}$ & $+0.05 \mathrm{pptv}$ & $+16 \%$ & - & - & $44.1 \%$ & - \\
\hline $\mathrm{HO}_{2}$ & +1.36 pptv & $+56 \%$ & - & - & $23.1 \%$ & - \\
\hline $\mathrm{O}_{3}$ & $-13.1 \mathrm{ppbv}$ & $-1.1 \%$ & $-12.6 \mathrm{ppbv}$ & $-1.1 \%$ & $22.5 \%$ & $26.3 \%$ \\
\hline
\end{tabular}

\subsection{Bromine compounds}

\subsubsection{Effect on BrO}

Coupling between chlorine and bromine compounds is of particular importance in the lower stratosphere (e.g. Lary et al., 1996; Erle et al., 1998; Salawitch et al., 2005). Heterogeneous bromine reactions are expected to increase the coupled gas-phase $\mathrm{ClO} / \mathrm{BrO}$ catalytic ozone destruction cycles. Because $\mathrm{BrONO}_{2}$ hydrolysis (Reaction $\mathrm{R} 4$ ) is not temperature dependent, its effects on the chemistry of the lower stratosphere are primarily dependent on the aerosol loading and not on latitude or SZA (Lary et al., 1996; Kondo et al., 1997; Erle et al., 1998).

Since direct injection of bromine into the stratosphere was insignificant after the Sarychev eruption (Hörmann et al., 2013), we expect that stratospheric bromine chemistry was only modified by the enhanced aerosol loading. BrO was the only key halogenated radical detected during the summer 2009 balloon campaign. Vertical profiles were provided by the SALOMON and DOAS instruments on 25 August 2009 and 7 September 2009 respectively (Fig. 10). They were simultaneously measured with the $\mathrm{NO}_{2}$ profiles presented in Sect. 3.2. Differences between both profiles in terms of $\mathrm{BrO}$ amounts are mainly due to differences in SZA. When volcanic aerosol SADs are included, $\mathrm{BrO}$ amounts are increased in the lower stratosphere, matching the observations within the error bars (Fig. 10).
Simulated results related to the bromine chemistry at $16.5 \mathrm{~km}$ are presented in Table 1 for the August-September 2009 period. During the daytime, part of the $\mathrm{BrO}$ enhancement is linked to the decreased loss by the three-body reaction with decreased $\mathrm{NO}_{2}$. The other part is expected to be controlled by $\mathrm{BrONO}_{2}$ hydrolysis, which is by far the most efficient bromine heterogeneous reaction in the temperature range observed in our study (Hanson and Ravishankara, 1995; Hanson et al., 1996). Under high aerosol loading the rate of the $\mathrm{BrONO}_{2}$ hydrolysis is likely to compete with the $\mathrm{BrONO}_{2}$ photolysis and with other gas-phase reactions which normally control the bromine partitioning during the daytime (Lary et al., 1996). Here, note that the conclusion of Kreycy et al. (2013) regarding a possibly larger ratio of the photolysis and the three-body formation reaction for $\mathrm{BrONO}_{2}\left(J\left(\mathrm{BrONO}_{2}\right) / k \mathrm{BrO}+\mathrm{NO}_{2}\right)$ than compiled by Sander et al. (2011) is not affected by the presence of the Sarychev aerosols in the lower stratosphere since they have addressed observations with $\mathrm{SZA}<92.5^{\circ}$ at $31 \mathrm{~km}$ (i.e. tangent heights $>24 \mathrm{~km}$ ). After sunset $\mathrm{BrONO}_{2}$ production is ceasing and its enhanced hydrolysis on volcanic aerosols leads to strongly increased formation of $\mathrm{HOBr}(+3.9 \mathrm{pptv}$ or $+141 \%)$ at an early stage of the night so that little $\mathrm{BrONO}_{2}$ remains before dawn. This conversion at night-time results in further release of $\mathrm{OH}$ and $\mathrm{Br}$ atoms in the morning through photolysis of $\mathrm{HOBr}$.

However, it is not clear if $\mathrm{BrONO}_{2}$ hydrolysis is mainly responsible for the increase in $\mathrm{BrO}$ within the lowermost stratosphere. Dedicated simulations to estimate the respec- 


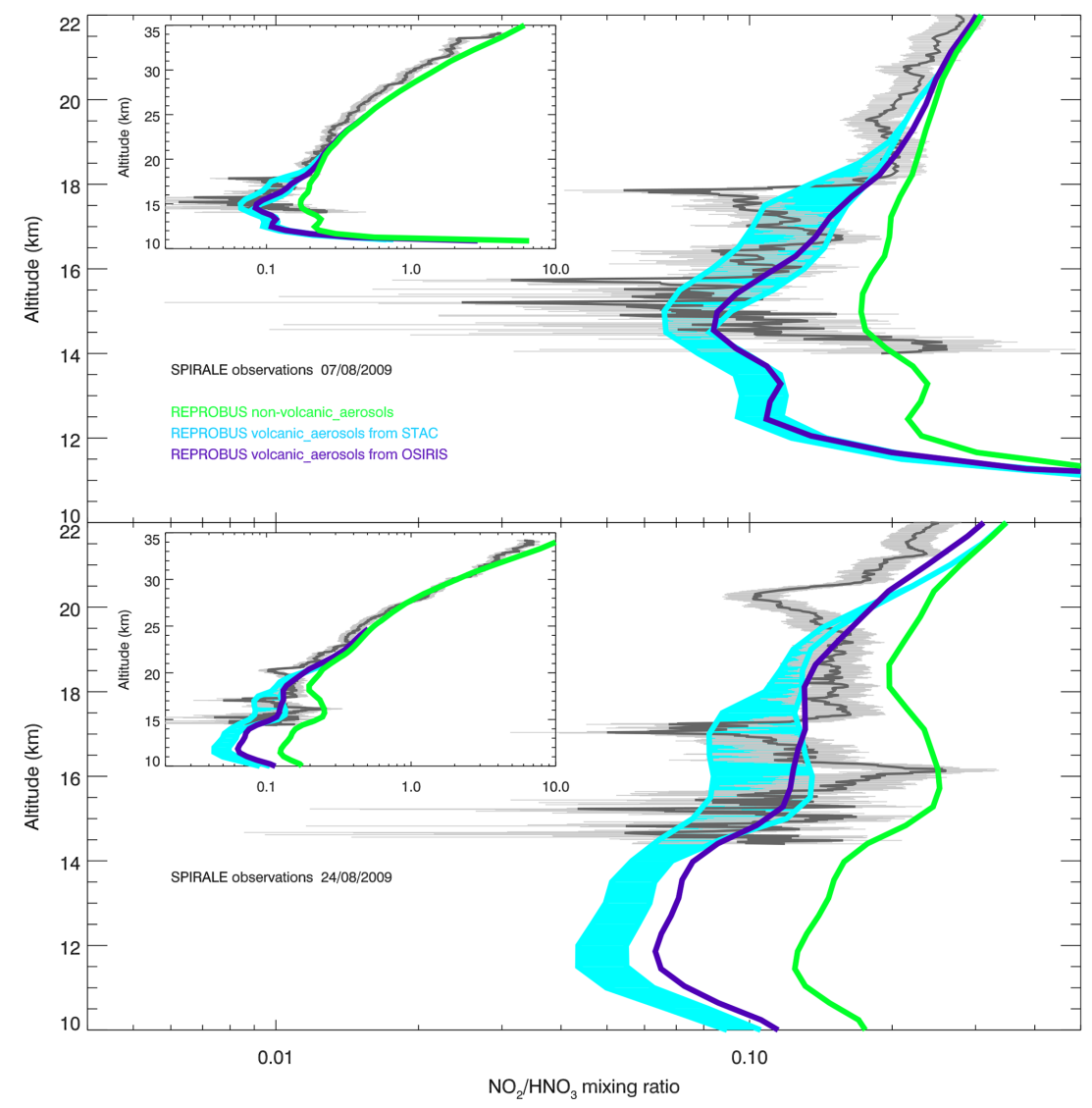

Figure 9. Same as Fig. 5 but for the $\mathrm{NO}_{2} / \mathrm{HNO}_{3}$ ratio observed by the SPIRALE instrument. Provided are the three-dimensional simulations driven without volcanic aerosols (green), with volcanic aerosols from balloon-borne observations (blue shaded area) and with volcanic aerosols from satellite data (dark blue line).

tive contribution of gas-phase chemistry and heterogeneous processes to the control of $\mathrm{BrO}$ production under volcanic conditions have thus been performed. The effects of the Sarychev aerosols on each chemical compound are calculated by switching off Reaction (R4) and compared in terms of percentage differences, with the simulations including all chemistry. Results are summarized in Table 1. It particularly shows that under the Sarychev aerosol loading, only $16 \%$ of the $22 \%$ (0.9 pptv) increase in daytime $\mathrm{BrO}$ at $16.5 \mathrm{~km}$ for the August-September 2009 period is produced from $\mathrm{BrONO}_{2}$ hydrolysis. This result implies that bromine chemistry in the gas phase coupled to processes controlling the $\mathrm{NO}_{y}$ partitioning mainly govern $\mathrm{BrO}$ amounts (e.g. Lary et al., 1996).

\subsubsection{Role of $\mathrm{BrONO}_{2}$ hydrolysis on other compounds}

As shown in Table 1 for an altitude of $16.5 \mathrm{~km}$, at night $\mathrm{BrONO}_{2}$ amounts are mainly affected by Reaction (R4), which controls $98 \%$ of its decrease under volcanic aerosol influence. Nearly $100 \%$ of the night-time $\mathrm{HOBr}$ production is due to $\mathrm{BrONO}_{2}$ hydrolysis, which accounts for $44 \%$ of the increase in $\mathrm{OH}$ radical amounts from the subsequent photolysis of $\mathrm{HOBr}$ at dawn. Therefore, under volcanic conditions, enhanced $\mathrm{BrONO}_{2}$ hydrolysis nearly matches the contribution of nitrogen chemistry (see Sect. 4.1) as a source of $\mathrm{OH}$ (e.g. Hanisco et al., 2001).

This additional release of $\mathrm{OH}$ radicals has significant consequences in the chemistry of the lower stratosphere. In our study the reduction in $\mathrm{NO}_{x}$ from $\mathrm{BrONO}_{2}$ hydrolysis is small (less than $2 \%$ ) as are the overall effects on nitrogen partitioning, confirming the conclusions of Lary et al. (1996) and Kondo et al. (1997). In contrast, there is substantial repartitioning of the active chlorine family species. The catalytic increase in $\mathrm{OH}$ due to the hydrolysis of $\mathrm{BrONO}_{2}$ leads to a reduction in the $\mathrm{HCl}$ lifetime, which is primarily dependent on the aerosol loading (Tie and Brasseur, 1996). The $\mathrm{OH}$ that is produced additionally converts remaining $\mathrm{HCl}$ to $\mathrm{ClO}$ and, ultimately, to $\mathrm{ClONO}_{2}$. As shown in Table 1 , $\sim 60 \%$ of the $\mathrm{HCl}$ decrease, $39 \%$ of the $\mathrm{ClO}$ increase and $66 \%$ of the $\mathrm{ClONO}_{2}$ increase is due to Reaction (R4) under the Sarychev aerosol loading, thus illustrating a significant enhancement of the coupling between the stratospheric chlorine and bromine photochemistry. 


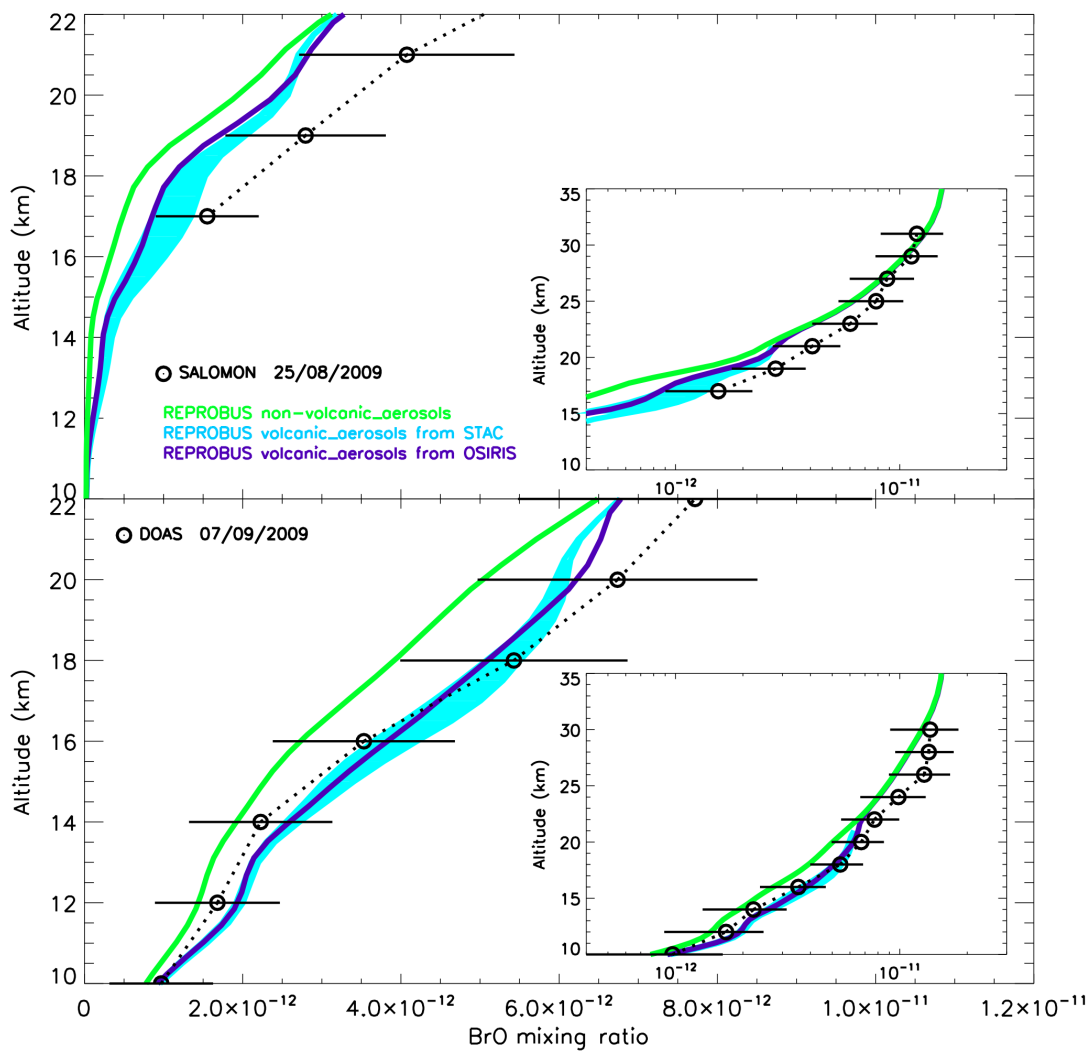

Figure 10. Same as Fig. 6 but for BrO. The SALOMON data in the lower stratosphere were obtained between 19:15 UT $\left(\mathrm{SZA}=93.8^{\circ}\right.$ at $22 \mathrm{~km}$ tangent height) and 19:25 UT (SZA $=94.5^{\circ}$ at $17 \mathrm{~km}$ tangent height). The DOAS profile was measured between 15:15 UT $\left(\mathrm{SZA}=77.5^{\circ}\right.$ at $\left.10 \mathrm{~km}\right)$ and $15: 55 \mathrm{UT}\left(\mathrm{SZA}=81.3^{\circ}\right.$ at $\left.22 \mathrm{~km}\right)$ during the balloon ascent.

\section{Stratospheric ozone}

\subsection{Chemical ozone change}

It is interesting to estimate the stratospheric ozone depletion induced by the Sarychev eruption. As said above, the model does not directly calculate possible effects of aerosols on stratospheric temperature and circulation. All our simulations use the same transport calculations, whereas ozone loss from Pinatubo in the northern midlatitudes can be both attributed to chemical and transport (such as increased tropical upwelling) effects (e.g. Telford et al., 2009; Dhomse et al., 2015). In the following, we therefore solely calculate the change in ozone due to photochemistry.

We then compare model simulations with enhanced and background aerosol levels (Fig. 11). Results indicate chemical reductions in ozone of a few percent following the eruption when aerosol levels are computed from the OSIRIS space-borne data. Accumulated ozone depletion reaches its maximum above Kiruna near $16 \mathrm{~km}$ from around midSeptember with changes of $-22 \mathrm{ppbv}$ corresponding to $-1.5 \%$. Below this level, changes range from -10 to -18 ppbv, i.e. -2.5 to $-3.5 \%$. From the upper bound of the Bal-sim outputs, calculated ozone depletion reaches
$-25 \mathrm{ppbv}(-2.8 \%)$ and $-35 \mathrm{ppbv}(-4 \%)$ at 16.5 and $14 \mathrm{~km}$ respectively (not shown).

We note that for the post-Pinatubo eruption period, ozone reductions as large as $-30 \%$ were measured for the 12 and $22 \mathrm{~km}$ altitude range monitored at some midlatitude locations in winter and spring (Hofmann et al., 1994), but these losses are both due to dynamical and chemical perturbations. Through 2-D modelling, ozone losses of up to $-20 \%$ directly resulting from heterogeneous chemical processes were calculated in the Northern Hemisphere lower stratosphere over the first year following the Pinatubo eruption (Pitari and Rizi, 1993; Tie et al., 1994). The calculated chemical loss had reduced to values much closer to those simulated for the Sarychev aerosols, i.e. $\sim-5 \%$, at $60^{\circ} \mathrm{N}$ in the autumn 1992 extra-polar vortex conditions (Tie et al., 1994).

\subsection{Chemical mechanisms for the ozone change in the lower stratosphere}

In the lower stratosphere, ozone removal rates are mainly controlled by the $\mathrm{HO}_{x}$ and halogen catalytic cycles which have been found to typically account for $30-50 \%$ and $30 \%$ of the total ozone loss respectively in non-volcanic conditions (Portmann et al., 1999; Salawitch et al., 2005). The 


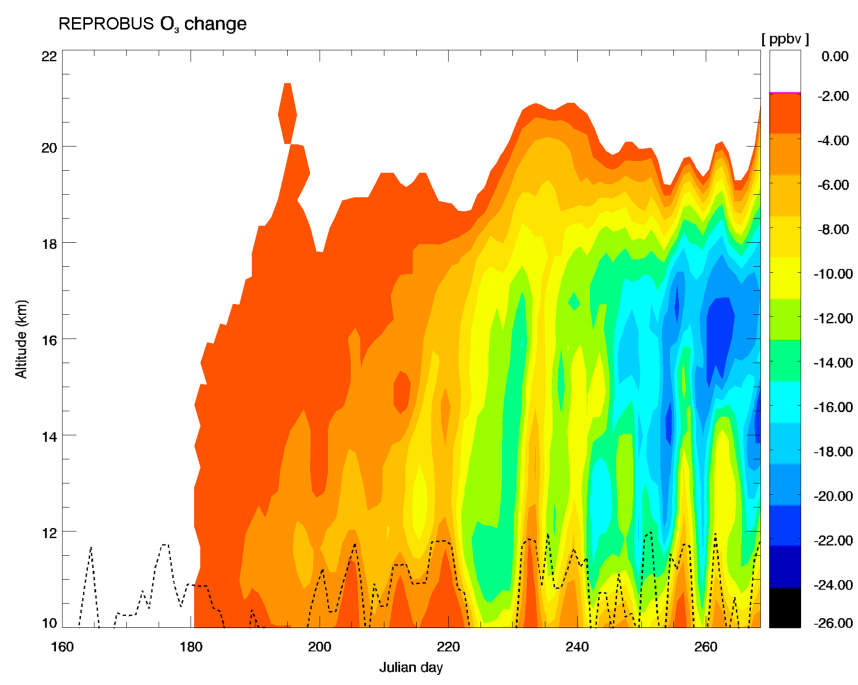

Figure 11. Changes in ozone over Kiruna $\left(67.5^{\circ} \mathrm{N}, 21.0^{\circ} \mathrm{E}\right)$ as a function of altitude and time between 1 July and 1 October 2009. Calculations are done by subtracting outputs from the volcanic simulation driven by OSIRIS observations with the background simulation. The position of the tropopause is given by the black dotted line.

$\mathrm{NO}_{x}$ cycles play a relatively minor role in the direct removal of ozone in the lower stratosphere, but, as a result of the coupling among the $\mathrm{NO}_{x}, \mathrm{HO}_{x}$ and halogen cycles, the rate of ozone removal is still very sensitive to the concentration of $\mathrm{NO}_{x}$ (Wennberg et al., 1994; Gao et al., 1999; Portmann et al., 1999; Salawitch et al., 2005). Through the reaction of $\mathrm{HO}_{2}$ with $\mathrm{NO}\left(\mathrm{HO}_{2}+\mathrm{NO} \rightarrow \mathrm{NO}_{2}+\mathrm{OH}\right)$, the decreased $\mathrm{NO}_{x}$ concentrations after the Sarychev eruption result in a larger $\mathrm{HO}_{2} / \mathrm{OH}$ ratio (as shown in Table 1) than for background conditions $\left(\mathrm{HO}_{2} / \mathrm{OH}\right.$ ratios typically ranging from 4 to 7). Because the photochemical removal of ozone in the lower stratosphere is dominated by processes involving $\mathrm{HO}_{2}$, catalytic ozone destruction by $\mathrm{HO}_{x}$ cycles is likely to be amplified after volcanic eruptions (Wennberg et al., 1994, 1995) though ozone loss rates are limited due to the saturation of the $\mathrm{NO}_{x} / \mathrm{NO}_{y}$ response. After the eruption of Sarychev, the effectiveness of halogen cycles is enhanced due to increased $\mathrm{ClO}_{x}$ resulting from an $\mathrm{OH}$ increase (Table 1) (as explained in Sect. 4.1). However, as said above, heterogeneous reactions activating chlorine are strongly and non-linearly dependent on temperature, implying slow rates in the average midlatitude temperature conditions (minimum values of $215 \mathrm{~K}$ ) (Hanson et al., 1994; Webster et al., 1998; Michelsen et al., 1999). Under these conditions the simulated depletion in ozone is restrained similarly to the finding of Tie et al. (1994) for the post-Pinatubo eruption period.

Part of the ozone depletion can be related to the coupled $\mathrm{BrO}_{x} / \mathrm{ClO}_{x}$ cycle, which is expected to be responsible for $20-25 \%$ of the halogen-controlled loss under non-volcanic aerosol conditions (Portmann et al., 1999; Salawitch et al.,
2005). Table 1 shows that the hydrolysis of $\mathrm{BrONO}_{2}$ accounts for more than $22 \%$ of the ozone loss at $16.5 \mathrm{~km}$ after the Sarychev eruption. As described in Sect. 4.2.2, this is due to Reaction (R4) acting as a source of $\mathrm{OH}$, reducing the $\mathrm{HCl}$ lifetime and thereby indirectly amplifying the chlorinemediated ozone depletion. Because the sticking coefficient for hydrolysis of $\mathrm{BrONO}_{2}$ on sulfate aerosols is not temperature dependent, this effect occurs at all latitudes and seasons in the lower stratosphere during high aerosol loading periods (Lary et al., 1996; Tie and Brasseur, 1996).

\section{Summary and conclusions}

Our study provides key observations of the chemical perturbation in the lower stratosphere by the moderate Sarychev volcano eruption in June 2009. Three- and one-dimensional CTM simulations are performed to interpret balloon-borne observations of some key chemical species made in the summer high-latitude lower stratosphere. The modelled chemical response to the volcanic aerosols is treated by comparing simulations using background aerosol levels and simulations driven by volcanic aerosol amounts inferred from balloonborne and space-borne observations.

Quantifying the impact of volcanic aerosols on stratospheric ozone chemistry is difficult as chemical and dynamical (radiative) effects occur simultaneously (Pitari and Rizi, 1993; Robock, 2000; Al-Saadi et al., 2001; Aquila et al., 2013). The model is a CTM driven by ECMWF offline meteorological data and does not describe radiative processes. In other words, volcanic aerosol radiative effects do not directly interact with the circulation computed by the model. Radiative processes from the injection of volcanic aerosols into the tropics have been shown to have an impact on mean meridional circulation and ozone transport (Brasseur and Granier, 1992; Pitari et Rizi, 1993). In our study, effects of the Sarychev aerosols on midlatitude stratospheric dynamics, if any, are at least of the first order intrinsically taken into account in the ECMWF analyses used for all simulations. REPROBUS does not take into account the aerosol impact on calculated photolysis rates, which is likely to result in some differences between models when this process is computed or ignored (Pitari and Rizi, 1993; Pitari et al., 2014). However, because the Sarychev eruption has only impacted the lower stratosphere at mid- and high latitudes the effect on the photolysis frequency of molecular oxygen and ozone due to absorption and backscattering of solar radiation by the volcanic aerosols is expected to be very small in these regions (Tie et al., 1994). Therefore, since all our simulations were driven with the same wind and temperature fields, our approach only estimates the chemical effects of the Sarychev aerosols.

The $\mathrm{NO}_{y}$ chemistry appears to be very sensitive to the increase in SAD within the lower stratosphere resulting from the Sarychev eruption. A decrease in the $\mathrm{NO}_{x}$ abundances is 
evident but shows some saturation as emphasized in a number of studies referring to cases of high sulfate aerosol loadings (e.g. Fahey et al., 1993). The effect of volcanic aerosols on nitrogen partitioning is also reflected in the calculated production of $\mathrm{HNO}_{3}$ as a result of the decrease in the $\mathrm{N}_{2} \mathrm{O}_{5}$ nitrogen reservoir from its enhanced hydrolysis and $\mathrm{NO}_{x}$ reduction.

Although direct comparisons in terms of solar illumination, latitude, injection altitudes and temperature are not possible for distinct volcanic eruptions such as Pinatubo and Sarychev, it is interesting to compare the effect of both eruptions on the photochemistry of the lower stratosphere. Overall, although different in magnitude, the eruptions of Pinatubo and Sarychev show a similar observed and simulated depletion of $\mathrm{NO}_{2}$, probably due to the saturation effect of the enhanced $\mathrm{N}_{2} \mathrm{O}_{5}$ hydrolysis. In comparison with the Pinatubo period, the Sarychev aerosols led to less overall $\mathrm{HNO}_{3}$ production in the stratosphere, possibly because the related $\mathrm{HNO}_{3}$ enhancement has been shown to be considerably weaker in the lowermost stratosphere (below $\sim 18 \mathrm{~km}$ ) than for sulfur injection into higher altitudes (Webster et al., 1994; Santee et al., 2004). However, one should note that previously reported modelling studies on the Pinatubo aerosols were conducted with previous chemical kinetic rate constants and photolysis rates which have mostly been updated since, which adds a degree of complexity to comparisons discussed within the present study.

For the Pinatubo aerosols, ozone destruction was not observed throughout the volcanic aerosol layer because $\mathrm{N}_{2} \mathrm{O}_{5}$ hydrolysis reduced $\mathrm{NO}_{x}$-related ozone loss, which even resulted in small increases in ozone in the middle stratosphere (Bekki and Pyle, 1994; Tie and Brasseur, 1995). For the Sarychev eruption, the volcanic aerosol layer is restrained to altitude levels below $19 \mathrm{~km}$ where the ozone destruction processes by $\mathrm{HO}_{x}$ and halogen catalytic cycles are expected to play a major role (e.g. Salawitch et al., 2005), with some sensitivity towards $\mathrm{NO}_{x}$ levels. To summarize, the increased production of $\mathrm{HNO}_{3}$ via $\mathrm{N}_{2} \mathrm{O}_{5}$ hydrolysis enhances the photolytic production of $\mathrm{OH}$ from $\mathrm{HNO}_{3}$. As a result, the gas-phase sink for $\mathrm{HCl}$ by reaction with $\mathrm{OH}$ is slightly enhanced and is associated with an increase in $\mathrm{ClO}$ amounts. An important result of the heterogeneous hydrolysis of $\mathrm{BrONO}_{2}$ is the formation and subsequent photolysis of additional $\mathrm{HOBr}$. The $\mathrm{OH}$ so produced additionally converts $\mathrm{HCl}$ to $\mathrm{ClO}$ (and ultimately to $\mathrm{ClONO}_{2}$ ). Accordingly, there is substantial repartitioning of the active chlorine, but effects of the $\mathrm{BrONO}_{2}$ hydrolysis on nitrogen partitioning are insignificant. In this chemical context, the magnitude of the ozone response to the Sarychev volcanic perturbation appears restricted (for instance, $-22 \mathrm{ppbv}$ or $-1.5 \%$ around $16 \mathrm{~km}$ ) because the saturation of the $\mathrm{NO}_{x} / \mathrm{NO}_{y}$ response limits the increase in $\mathrm{HO}_{x}$ and in active chlorine $(\mathrm{ClO})$ by enhanced $\mathrm{HO}_{x}$, precluding important ozone loss rates. Moreover, stratospheric temperatures remained too high (i.e. mainly above $215 \mathrm{~K}$ ) for efficient heterogeneous conversion of $\mathrm{ClONO}_{2}$ to active chlorine, which could have led to significant ozone depletion. For these temperature conditions, Reaction (R2) is not expected to compete with $\mathrm{N}_{2} \mathrm{O}_{5}$ hydrolysis in the $\mathrm{NO}_{y}$ partitioning (Fahey et al., 1993; Cox et al., 1994).

However, limitations in our model simulations also contribute to some model-measurement discrepancies. A first major difficulty is to drive the model simulations with representative and consistent inputs in term of volcanic aerosol loading. To address this issue, two different model runs for aerosol forcing have been performed, one using OSIRIS satellite data converted to aerosol SAD fields and the other one from in situ balloon-borne observations. The OSIRIS satellite data represent zonally and daily averaged values of $\mathrm{SAD}$, which may vary from a 3-D construction based on the local surface areas. The possible presence of aerosol streamers (geographical variations in the aerosol content) resulting from the transport of the volcanic aerosols over the Northern Hemisphere present from mid-July to September 2009 is likely to affect the $\mathrm{N}_{2} \mathrm{O}_{5}$ abundances locally and regionally and, to a lesser extent, $\mathrm{NO}_{2}$ and $\mathrm{HNO}_{3}$ (Jucks et al. 1999; Küll et al., 2002). If our aerosol SAD dataset had been obtained when the local concentrations were higher than the zonal mean values, then the calculated rate of the heterogeneous reactions would be biased low and calculated $\mathrm{NO}_{x}$ and $\mathrm{HNO}_{3}$ abundances would be systematically biased high and low respectively. This is not, however, evident in all our comparisons from simulations based on OSIRIS aerosols. The second type of aerosol-constrained simulation uses SADs from balloon-borne observed profiles. By definition, such in situ observations deal with a particular location. Extrapolating in situ derived SADs to drive a 3-D model on a large scale may induce inaccurate simulations of the chemical impact of the aerosols (Kondo et al., 2000). To account for this SADrelated uncertainty, our simulations based on in situ data encompass the range of SADs derived from the STAC balloonborne observations over the August-September 2009 period. Both satellite- and balloon-driven simulations give similar results in terms of $\mathrm{NO}_{2}$ and $\mathrm{HNO}_{3}$ amounts, possibly because the in situ observations represent the aerosol loading at the northern midlatitudes well. Another explanation is that the saturation effect (roughly when SADs become larger than $3 \mu \mathrm{m}^{2} \mathrm{~cm}^{-3}$ ) of the $\mathrm{NO}_{x} / \mathrm{NO}_{y}$ ratio is more relevant for the range of observed SADs than spatiotemporal inhomogeneities.

Secondly, adequate modelling of transport is also crucial for the partitioning of $\mathrm{NO}_{y}$. Processes that control the vertical profiles of $\mathrm{NO}_{2}$ and $\mathrm{HNO}_{3}$ in the stratosphere are based on a complex interplay between dynamics and chemistry with the key issue being to accurately simulate total $\mathrm{NO}_{y}$, which may be not systematically achieved with 3-D CTM calculations. Improved simulations of transport can be obtained by combing operational analyses with forecasts to construct 3-hourly meteorological data to drive the CTM (Berthet et al., 2006). We have applied this strategy in the 
present study. Using 1-D modelling driven by in situ observations or calculating $\mathrm{NO}_{2} / \mathrm{HNO}_{3}$ ratios to reduce transport effects does not clearly improve the model-measurement comparisons for the lower stratosphere. Although some features in the vertical profiles are not systematically captured by the model, this tends to indicate that the error in calculated transport is not large enough to account for the overall difference between measured and modelled $\mathrm{NO}_{2}$ and $\mathrm{HNO}_{3}$ when no volcanic aerosol loading is included in the model. Rather, these results show some evidence of the role of heterogeneous reactions at the surface of volcanic aerosols.

Thirdly, part of the discrepancies between model and observations might be attributed to spatial resolution issues. It may be tricky to compare model calculations with highresolution in situ profiles and with remote-sensing observations integrating over tens of kilometres (Berthet et al., 2007). For instance, discrepancies between remote-sensing observations and model calculations have been reported for stratospheric $\mathrm{NO}_{3}$ in the case of localized temperature inhomogeneities as a result of the strong dependence of $\mathrm{NO}_{3}$ cross sections and kinetics on temperature (Renard et al., 2001). $\mathrm{N}_{2} \mathrm{O}_{5}$ and $\mathrm{NO}_{2}$ may be subsequently impacted because $\mathrm{NO}_{3}$, together with $\mathrm{NO}_{2}$, plays a central role in the equilibrium reaction controlling $\mathrm{N}_{2} \mathrm{O}_{5}$ in the gas phase.

In our study, no comprehensive sulfur chemistry is included in the model. We have also excluded dynamical and radiative effects on the ozone response, which have been shown to be of primary importance when dense volcanic clouds are present (e.g. Pitari and Rizi, 1993; Kinnison et al., 1994; Tie et al., 1994; Al-Saadi et al., 2001). In a forthcoming study it would be interesting to compare dynamical or radiative and chemical effects of moderate volcanic eruptions on stratospheric ozone using chemistry-climate models with full sulfur chemistry and aerosol-dynamics interactive calculations.
Finally, it might be interesting to investigate the effects of other volcanic plumes coming from moderate volcanic eruptions which are then transported to high-latitude regions when stratospheric temperatures are more favourable for chlorine activation and enhanced ozone loss (e.g. in winter). The activation of chlorine from volcanic sulfate aerosols and associated ozone depletion is arguably more significant in the cold temperature conditions of winter and spring, even above the formation threshold of polar stratospheric clouds (Hanson et al., 1994). The eruption of the Calbuco volcano in the Southern Hemisphere in April 2015 could be a good candidate for a study of this process (Solomon et al., 2016).

\section{Data availability}

Balloon data can be accessed on the ESPRI database (ESPRI data Centre, http://ether.ipsl.jussieu.fr/etherTypo/index.php? $\mathrm{id}=1538 \& \mathrm{~L}=1)$ and are sorted by instrument names (ESPRI data Centre, 2016). 


\section{Appendix A: Technical description}

\section{A1 The STAC aerosol counter}

Aerosol size distributions are provided in the $0.4-5 \mu \mathrm{m}$ diameter size range (Ovarlez and Ovarlez, 1995; Renard et al., 2008). Since 2008, the number of available size classes has been increased from 7 to 14 within this size range (Renard et al., 2010). The counting uncertainty is obtained from the statistical probability given by Poisson counting statistics (Willeke and Liu, 1976). This uncertainty, defined as the relative standard deviation, is $60 \%$ for aerosol concentrations of $10^{-3} \mathrm{~cm}^{-3}, 20 \%$ for $10^{-2} \mathrm{~cm}^{-3}$ and $6 \%$ for concentrations higher than $10^{-1} \mathrm{~cm}^{-3}$. Laboratory comparisons between two copies of the STAC aerosol counter using identical aerosol samples have shown differences of $\pm 10 \%$ for concentrations higher than $10^{-2} \mathrm{~cm}^{-3}$. From these results, we define a measurement precision limited to $\pm 10 \%$. It should be noted that comparisons with the aerosol concentrations measured by the University of Wyoming optical particle counter (Deshler et al., 2003) have shown consistent results between both instruments (Renard et al., 2002). STAC is calibrated in order to provide size distributions of non-absorbing liquid aerosols which have been unambiguously observed in the $8-19 \mathrm{~km}$ altitude range in the case of the Sarychev eruption (Jégou et al., 2013). Aerosol distribution moments are derived using well-known analytical expressions. Using a statistical approach as described in Deshler et al. (2003), STAC counting precision (Poisson statistics and the $\pm 10 \%$ measurement reproducibility) translate into uncertainties in distribution moments, with estimated values of $40 \%$ for SAD. Profiles are typically averaged over a vertical range of $250 \mathrm{~m}$ (corresponding to $\sim 1 \mathrm{~min}$ of measurements).

\section{A2 The SPIRALE in situ infrared spectrometer}

A detailed description of the instrumental characteristics of SPIRALE and of its operating mode can be found in Moreau et al. (2005). Six tunable laser diodes emitting in spectral micro-windows $\left(<1 \mathrm{~cm}^{-1}\right)$ in the mid-infrared domain $(1250$ to $3000 \mathrm{~cm}^{-1}$ ) are used for in situ measurements of trace gas species from the upper troposphere to the stratosphere. The six laser beams are injected into a multipass Heriott cell, comprising two mirrors spaced $3.50 \mathrm{~m}$ apart by a telescopic mast, allowing for $434.0 \mathrm{~m}$ optical path. This cell is deployed under the gondola during the flight above $\sim 9 \mathrm{~km}$ altitude, i.e. when pressure is below $\sim 300 \mathrm{hPa}$ and thus absorption lines are significantly narrower than the scanned micro-windows. Species concentrations are retrieved from direct absorption, by fitting experimental spectra with spectra calculated using the HITRAN (high-resolution transmission molecular absorption database) 2012 database (Rothman et al., 2013) and the temperature and pressure measured on board the gondola. Measurements of pressure (by two calibrated and temperature-regulated capacitance manometers) and temperature (by two probes made of resistive platinum wire) allow for the conversion of the species concentrations to volume mixing ratios. Uncertainties in these parameters are negligible regarding the other uncertainties discussed below. The instrument provides measurements every $1.1 \mathrm{~s}$; thus, measurements have a vertical resolution of a few metres depending on the vertical velocity of the balloon ( 2 to $5 \mathrm{~m} \mathrm{~s}^{-1}$ ). Absorption lines in the micro-windows 1260.95-1261.25, 1598.451598.85 and $1701.50-1701.80 \mathrm{~cm}^{-1}$ were selected for $\mathrm{N}_{2} \mathrm{O}$, $\mathrm{NO}_{2}$ and $\mathrm{HNO}_{3}$ respectively. The total error for the volume mixing ratios has been assessed by taking into account the random errors and the systematic errors and combining them as the square root of their quadratic sum (Moreau et al., 2005). There are two important sources of random errors: (1) the fluctuations of the laser background emission signal and (2) the signal-to-noise ratio. These error sources are the main contributions for $\mathrm{NO}_{2}$ giving a total uncertainty of $30 \%$ at the lower altitudes (around $15 \mathrm{~km}$ ), gradually reduced to $20 \%$ around $20 \mathrm{~km}$ and decreasing to $5 \%$ at higher altitudes (above $30 \mathrm{~km}$ ). For $\mathrm{HNO}_{3}$ these random errors are less significant, but two sources of systematic errors have to be considered: the laser line width (an intrinsic characteristic of the laser diode) and the non-linearity of the detectors resulting in an uncertainty of $20 \%$ on the whole profile. Concerning $\mathrm{N}_{2} \mathrm{O}$ and ozone, which are abundant and measured using detection systems with a proper linearity of the photovoltaic conversion, the overall uncertainties are $3 \%$ over the whole vertical profile, and decrease from $10 \%$ at $14 \mathrm{~km}$ (i.e. for mixing ratios below $1 \mathrm{ppmv}$ ) to $5 \%$ above $17 \mathrm{~km}$. With respect to the above errors, systematic errors on spectroscopic data (essentially molecular line strength and pressure broadening coefficients) are considered to be negligible for these well-studied species (Rothman et al., 2013). SPIRALE was used routinely during the 2000s, in particular as part of European projects and satellite validation campaigns (Grossel et al., 2010; Mébarki et al., 2010; Krysztofiak et al., 2012, 2015, and references therein).

\section{A3 The DOAS remote-sensing UV-visible spectrometer}

Direct solar spectra from two UV-visible DOAS spectrometers are collected onboard the azimuth-controlled LPMA/DOAS (Limb Profile Monitor of the Atmosphere/Differential Optical Absorption Spectroscopy) balloon payload which carries a sun tracker (Hawat et al., 1995). The solar reference spectrum is usually the spectrum for which the air mass along the line of sight and the residual trace gas absorption are minimal. The residual absorption in the solar reference is determined using Langley's extrapolation to zero air mass. Rayleigh and Mie scattering are accounted for by including a third-order polynomial in the fitting procedure. The relative wavelength alignment of the absorption cross sections and the solar reference spectrum is fixed and only the measured spectrum is allowed to shift and 
stretch. $\mathrm{O}_{3}$ SCDs are retrieved from the differential structures in the Chappuis absorption band between 545 and $615 \mathrm{~nm}$. The line-of-sight absorptions of $\mathrm{NO}_{2}$ are inferred from the 435 to $485 \mathrm{~nm}$ wavelength range. Two $\mathrm{O}_{3}$ absorption cross sections recorded in the laboratory at 230 and $244 \mathrm{~K}$, aligned to cross sections from Voigt et al. (2001), are orthogonalized and fitted simultaneously. Broadband spectral features are represented by a fourth-order polynomial. Additional complications arise from the temperature dependence of the $\mathrm{NO}_{2}$ absorption cross section (Pfeilsticker et al., 2000). The $\mathrm{NO}_{2}$ analysis is performed using absorption cross sections recorded in the laboratory, scaled and aligned to convolved and orthogonalized cross sections from Harder et al. (1997) taken at 217 and $230 \mathrm{~K}$. The error bars of the retrieved SCDs are estimated via Gaussian error propagation mainly from the statistical error given by the fitting routine, the error in determining the residual absorber amount in the solar reference spectrum and the errors of the absorption cross sections. In total, typical accuracies of the DOAS $\mathrm{O}_{3}$ and $\mathrm{NO}_{2}$ measurements are better than 5 and $10 \%$ respectively. The retrieval process for $\mathrm{NO}_{2}$ is described in Butz et al. (2006).

Bromine monoxide ( $\mathrm{BrO})$ is detected in the UV wavelength range from 346 to $360 \mathrm{~nm}$ as recommended by Aliwell et al. (2002). This wavelength range contains the UV vibration absorption bands ( $4-0$ at $354.7 \mathrm{~nm}$ and $5-0$ at $348.8 \mathrm{~nm}$ ) of the $\mathrm{A}\left({ }^{2} \pi\right) \leftarrow \mathrm{X}\left({ }^{2} \pi\right)$ electronic transition of BrO. Typical optical densities are $10^{-4}-10^{-3}$ for UV vibration absorption bands. The set of reference spectra used contains an $\mathrm{NO}_{2}$ reference spectrum for $T=233 \mathrm{~K}$ and two $\mathrm{O}_{3}$ spectra at $T=197 \mathrm{~K}$ and $T=253 \mathrm{~K}$ in order to account for temperature effects. All $\mathrm{NO}_{2}$ and $\mathrm{O}_{3}$ spectra were recorded with the balloon spectrograph in the laboratory. The $\mathrm{BrO}$ reference is the absolute cross section measured by Wahner et al. (1988), with the wavelength calibration taken from our own laboratory measurements. Profile information was obtained by a least-squares profile inversion technique (maximum a posteriori) (Rodgers, 2000). Further details on the BrO DOAS retrieval and the profile inversion can be found in Harder et al. (1998, 2000), Aliwell et al. (2002), Dorf et al. (2006b) and Kreycy et al. (2013). Data are available at http://www. pole-ether.fr/etherTypo/index.php?id=1695\&L=1.

\section{A4 The SALOMON remote-sensing UV-visible spectrometer}

The data presented in this study were obtained using a Système d'Analyse par Observation Zénithale (SAOZ)-type UV-visible spectrometer (Pommereau and Piquard, 1994) connected to a sun and moon tracker for the detection of ozone and $\mathrm{NO}_{2}$ amounts. The one-band spectral window of SALOMON between 400 and $950 \mathrm{~nm}$ is adequate for the retrieval of absorption features over large spectral ranges, i.e. roughly from 400 to $680 \mathrm{~nm}$ for ozone and from 400 to $550 \mathrm{~nm}$ for $\mathrm{NO}_{2}$. The spectrum recorded at float altitude (more than $36.5 \mathrm{~km}$ ) corresponds to a minimum air mass and is considered as a reference spectrum. Occultation spectra recorded for elevation angles between 0 and $-5^{\circ}$ below the gondola horizon are taken into account for the retrieval of the SCDs. Owing to the thermal insulation of the spectrometer, no spectral drift of the Fraunhofer lines and no instrumental resolution changes have been observed between the reference and the occultation spectra. The Rayleigh scattering contribution is calculated and removed from the spectra using these profiles and the spectral cross sections given by Bucholtz (1995). Then, $\mathrm{O}_{3}$ and $\mathrm{NO}_{2}$ SCDs are determined by least-squares fits using the University of Bremen high-resolution absorption cross sections convolved to the spectral resolution of the instrument (data available from http://www.iup.uni-bremen.de/gruppen/ molspec/databases/index.html). Aerosols are a major lowfrequency spectral contribution, which is removed by a highpass filter to derive the $\mathrm{NO}_{2} \mathrm{SCDs}$. All lines of sight are not used to derive SCDs since the retrieval is performed only when signal-to-noise ratios (computed in our case by the ratio of the fit maximum amplitude to the standard deviation between the measurement and the fit) are greater than $1 . \mathrm{NO}_{2}$ fitting errors are typically $5-9 \%$ for SCDs crossing the altitude levels of the volcanic aerosol layer (i.e. below $\sim 19 \mathrm{~km}$ ). Vertical concentration profiles have been derived using an a posteriori least-squares inversion technique (Rodgers et al., 2000), taking into account the fitting error and the uncertainties of the cross sections. Note that the data reduction method used in this study is described by Renard et al. (2000) and Berthet et al. (2002).

For the flight presented in this study we have added an HR4000 UV spectrometer from Ocean Optics to detect $\mathrm{BrO}$ absorption lines in the $346-360 \mathrm{~nm}$ range as done for the DOAS instrument. The spectrometer is thermally insulated and regulated using Peltier devices to avoid spectral shifts. It has its own connection to the sun tracker but collects the sunlight simultaneously with a Jobin Yvon UV-visible spectrometer. We use the same data reduction method as for DOAS as described in detail by Dorf et al. (2006b) to retrieve SCDs and the vertical profile of $\mathrm{BrO}$. In our case the Wahner et al. (1988) $\mathrm{BrO}$ and Bremen ozone and $\mathrm{NO}_{2}$ cross sections are convolved to the resolution of the instrument, determined in the laboratory using a UV lamp. SCD data are smoothed to increase the signal-to-noise ratio. The altitude grid for profile inversion is $2 \mathrm{~km}$. Associated random errors are those provided by the spectral fit. The major systematic error comes from the uncertain estimation of the residual BrO column above float altitude. Data are available at http: //www.pole-ether.fr/etherTypo/index.php?id=1200\&L=1.

\section{Appendix B: Model description}

The REPROBUS 3-D CTM computes the evolution of 55 species by means of about 160 photolytic gas-phase and heterogeneous reactions, with a time step of $15 \mathrm{~min}$ in this study. 
A semi-Lagrangian code transports 40 species or chemical families, typically long-lived tracers but also more unstable compounds (Lefèvre et al., 1994, 1998).

Temperature, winds and surface pressure are specified from the 3-D ECMWF meteorological data from the surface up to $0.01 \mathrm{hPa}$ (i.e. about $80 \mathrm{~km}$ in altitude) on 91 levels. This results in a vertical resolution of about $0.45 \mathrm{~km}$ in the lower stratosphere. REPROBUS is driven by 3-hourly ECMWF wind fields obtained by interleaving operational analysis and forecasts because in this way spurious calculation of transport is reduced in comparison with simulations based on 6hourly analysis (Legras et al., 2005; Berthet et al., 2006).

Gas-phase kinetics parameters used in the present study are based on the recommendation by the Jet Propulsion Laboratory (JPL) described in Sander et al. (2011). In particular for nitrogen gas-phase chemistry, revised kinetic data were recommended because, following a number of studies (e.g. Brown et al., 1999; Gao et al., 1999; Jucks et al., 1999; Osterman et al., 1999; Kondo et al., 2000; Prasad, 2003), a lower rate for the reaction of $\mathrm{NO}_{2}$ with $\mathrm{OH}$ and a higher rate for $\mathrm{HNO}_{3}$ with $\mathrm{OH}$ significantly reduced model-measurement discrepancies highlighted in former published work (e.g. Fahey et al., 1993; Kondo et al., 1997; Sen et al., 1998).

The heterogeneous chemistry module includes reactions on liquid aerosols. An analytical expression is used to calculate the equilibrium composition and volume of the $\mathrm{H}_{2} \mathrm{SO}_{4}-$ $\mathrm{H}_{2} \mathrm{O}$ droplets as a function of temperature and the total amounts of $\mathrm{H}_{2} \mathrm{O}$ and $\mathrm{H}_{2} \mathrm{SO}_{4}$ (Carslaw et al., 1995). The routine calculates the aqueous phase concentrations for the soluble species $\mathrm{HCl}, \mathrm{HBr}, \mathrm{HOCl}$ and $\mathrm{HOBr}$ to calculate the rates of the heterogeneous reactions involving these compounds on stratospheric liquid aerosols. Reactions of $\mathrm{N}_{2} \mathrm{O}_{5}, \mathrm{ClONO}_{2}$ and $\mathrm{BrONO}_{2}$ on/in sulfuric acid are usually dependent on the species' Henry's law solubility and liquid phase diffusion coefficient in the liquid as well as the surface and/or liquid phase reaction rates (Hanson et al., 1994; Shi et al., 2001; Sander et al., 2011). $\mathrm{N}_{2} \mathrm{O}_{5}$ hydrolysis takes place at the surface of the particles (Hanson et al., 1994). As in a number of previous studies (e.g. Mills et al., 1993; Gao et al., 1999; Bracher et al., 2005), REPROBUS computes a $\gamma$ reaction efficiency of 0.1 as default value $(0.05-0.2$ in Sander et al., 2011), which is independent of temperature and acid composition. The reaction rate is proportional to $\gamma$ and increases with aerosol SAD. For heterogeneous reactions involving $\mathrm{ClONO}_{2}$, kinetics are taken from the well-detailed uptake model of Shi et al. (2001), which uses the parameterization of the $\mathrm{H}_{2} \mathrm{SO}_{4} / \mathrm{H}_{2} \mathrm{O}$ composition of Tabazadeh et al. (1997). These processes are strong functions of the acid composition and temperature. Note that the $\gamma$ reaction efficiency for $\mathrm{ClONO}_{2}$ described in the JPL recommendation of Sander et al. (2011) is taken from Shi et al. (2001). The $\mathrm{BrONO}_{2}$ reactivity on sulfuric acid particles is computed from the JPL parameterization which is based on the work of Hanson (2003) and shows a rather limited dependence on acid composition and temperature.
Initialized amounts of species are taken from a longterm simulation from the UPMC 2-D model (Bekki and Pyle, 1994; Weisenstein and Bekki, 2006). The initialization of stratospheric chlorine precursors is based on scenarios defined by the World Meteorological Organization (WMO, 2014). Total inorganic chlorine $\left(\mathrm{Cl}_{y}=\mathrm{HCl}+\mathrm{ClONO}_{2}+\mathrm{HOCl}+\mathrm{ClO}+\mathrm{Cl}_{2} \mathrm{O}_{2}\right)$ is calculated by the model and approaches $3.3 \mathrm{ppbv}$ in the upper stratosphere in 2009, in accordance with the WMO (2014). Note that as expected, this value is reduced compared to the study (3.7 ppbv) by Berthet et al. (2005). Total stratospheric inorganic bromine takes into account the contributions from Halons, methyl bromide and very-short-lived bromine compounds to reach $19.5 \mathrm{pptv}$, matching the scenario given by WMO (2010) updated from Dorf et al. (2006a).

Gaseous sulfur chemistry is not included in the REPROBUS CTM. The UPMC 2-D model climatology (Bekki and Pyle, 1994) provides the initialization of $\mathrm{H}_{2} \mathrm{SO}_{4}$ mixing ratios for the background aerosols. Liquid particles are formed in equilibrium and are assumed to have a predefined number density. Mean particle radii and SADs of the liquid aerosols are calculated from the number density and the amount of $\mathrm{H}_{2} \mathrm{SO}_{4}$ and $\mathrm{H}_{2} \mathrm{O}$ assuming a lognormal unimodal distribution with a fixed distribution width. 
Competing interests. The authors declare that they have no conflict of interest.

Acknowledgements. The authors are grateful to the CNES (Centre National d'Etudes Spatiales) balloon launching team for successful operations and the Swedish Space Corporation at Esrange. The StraPolÉté project and the associated balloon campaign has been funded by the French "Agence Nationale de la Recherche" (ANR-BLAN08-1-31627), CNES, and the "Institut Polaire PaulEmile Victor" (IPEV). The study is supported by the French Labex "Étude des géofluides et des VOLatils-Terre, Atmosphère et Interfaces - Ressources et Environnement" (VOLTAIRE) (ANR-10-LABX-100-01) managed by the University of Orleans. The ETHER database (CNES-INSU/CNRS) is a partner of the project. Further support for the DOAS balloon measurements came through the Deutsche Forschungsgemeinschaft, DFG (grants PF384/5-1 and 384/5-1 and PF384/9-1/2) and the European projects EU projects Reconcile (FP7-ENV-2008-1-226365) and SHIVA (FP7-ENV-2007-1-226224). We thank Michel Van Roozendael and Caroline Fayt from BIRA/IASB in Belgium for making available the WINDOAS algorithm in a form very well-adapted to data reduction methods based on the differential optical absorption technique. We acknowledge the MIPAS/Envisat team from Karlsruhe Institute of Technology (KIT) for making IMK/IAA data available.

Edited by: A. Engel

Reviewed by: two anonymous referees

\section{References}

Aliwell, S., Van Roozendael, M., Johnston, P., Richter, A., Wagner, T., Arlander, D., Burrows, J., Fish, D., Jones, R., Tornkvist, K., Lambert, J.-C., Pfeilsticker, K., and Pundt, I.: Analysis for $\mathrm{BrO}$ in zenith-sky spectra: An intercomparison exercise for analysis improvement, J. Geophys. Res., 107, 4199, doi:10.1029/2001JD000329, 2002.

Al-Saadi, J., Pierce, R., Fairlie, T., Kleb, M., Eckman, R., Grose, W., Natarajan, M., and Olson, J.: Response of middle atmosphere chemistry and dynamics to volcanically elevated sulfate aerosol: Three-dimensional coupled model simulations, J. Geophys. Res., 106, 27255-27275, 2001.

Aquila, V., Oman, L. D., Stolarski, R., Douglass, A. R., and Newman, P. A.: The response of ozone and nitrogen dioxide to the eruption of Mt. Pinatubo at southern and northern midlatitudes, J. Atmos. Sci., 70, 894-900, 2013.

Bekki, S. and Pyle, J. A.: A two-dimensional study of the volcanic eruption of Mount Pinatubo, Geophys. Res. Lett., 99, 1886118869, 1994.

Berthet, G., Renard, J.-B., Brogniez, C., Robert, C., Chartier, M., and Pirre, M.: Optical and physical properties of stratospheric aerosols from balloon measurements in the visible and nearinfrared domain: 1. Analysis of aerosol extinction spectra from the AMON and SALOMON instruments, Appl. Optics, 41, 7522-7539, 2002.

Berthet, G., Ricaud, P., Lefèvre, F., Le Flochmoën, E., Urban, J., Barret, B., Lautié, N., Dupuy, E., De La Noë, J., and Murtagh, D.:
Nighttime chlorine monoxide observations by the Odin satellite and implications on the $\mathrm{Cl}_{2} \mathrm{O}_{2} / \mathrm{ClO}$ equilibrium, Geophys. Res. Lett., 32, L11812, doi:10.1029/2005GL022649, 2005.

Berthet, G., Huret, N., Lefèvre, F., Moreau, G., Robert, C., Chartier, M., Catoire, V., Barret, B., Pisso, I., and Pomathiod, L.: On the ability of chemical transport models to simulate the vertical structure of the $\mathrm{N}_{2} \mathrm{O}, \mathrm{NO}_{2}$ and $\mathrm{HNO}_{3}$ species in the mid-latitude stratosphere, Atmos. Chem. Phys., 6, 1599-1609, doi:10.5194/acp-6-1599-2006, 2006.

Berthet, G., Renard, J.-B., Catoire, V., Chartier, M., Robert, C., Huret, N., Coquelet, F., Bourgeois, Q., Rivière, E. D., Barret, B., Lefèvre, F., and Hauchecorne, A.: Remote sensing measurements in the polar vortex: comparison to in situ observations and implications for the simultaneous retrievals and analysis of the $\mathrm{NO}_{2}$ and OClO species, J. Geophys. Res., 112, D21310, doi:10.1029/2007JD008699, 2007.

Borrmann, S., Solomon, S., Dye, J. E., Baumgardner, D., Kelly, K. K., and Roland Chan, K.: Heterogeneous reactions on stratospheric background aerosols, volcanic sulfuric acid droplets, and type I polar stratospheric clouds: Effects of temperature fluctuations and differences in particle phase, J. Geophys. Res., 102, 3639-3648, 1997.

Bourassa, A. E., Rieger, L. A., Lloyd, N. D., and Degenstein, D. A.: Odin-OSIRIS stratospheric aerosol data product and SAGE III intercomparison, Atmos. Chem. Phys., 12, 605-614, doi:10.5194/acp-12-605-2012, 2012.

Bracher, A., Sinnhuber, M., Rozanov, A., and Burrows, J. P.: Using a photochemical model for the validation of $\mathrm{NO}_{2}$ satellite measurements at different solar zenith angles, Atmos. Chem. Phys., 5, 393-408, doi:10.5194/acp-5-393-2005, 2005.

Brasseur, G. and Granier, C.: Mount Pinatubo aerosols, chlorofluorocarbons and ozone depletion, Science, 257, 1239-1242, 1992.

Brohede, S., McLinden, C. A., Berthet, G., Haley, C. S., Murtagh, D., and Sioris, C. E.: Stratospheric $\mathrm{NO}_{2}$ Climatology from Odin/OSIRIS Limb Scattering Measurements, Can. J. Phys., 85, 1253-1274, 2007.

Brohede, S., McLinden, C. A., Urban, J., Haley, C. S., Jonsson, A. I., and Murtagh, D.: Odin stratospheric proxy $\mathrm{NO}_{\mathrm{y}}$ measurements and climatology, Atmos. Chem. Phys., 8, 5731-5754, doi:10.5194/acp-8-5731-2008, 2008.

Brown, S. S., Talukdar, R. K., and Ravishankara, A. R.: Rate constants for the reaction $\mathrm{OH}+\mathrm{NO}_{2}+\mathrm{M} \rightarrow \mathrm{HNO}_{3}+\mathrm{M}$ under atmospheric conditions, Chem. Phys. Lett., 299, 277-284, 1999.

Brühl, C., Crutzen, P. J., and Grooss, J.-U.: High-latitude, summertime $\mathrm{NO}_{x}$ activation and seasonal ozone decline in the lower stratosphere: Model calculations based on observations by HALOE on UARS, J. Geophys. Res., 103, 3597-3597, 1998.

Bucholtz, A.: Rayleigh-scattering calculations for the terrestrial atmosphere, Appl. Optics, 34, 1227-1230, 1995.

Butz, A., Bösch, H., Camy-Peyret, C., Chipperfield, M., Dorf, M., Dufour, G., Grunow, K., Jeseck, P., Kühl, S., Payan, S., Pepin, I., Pukite, J., Rozanov, A., von Savigny, C., Sioris, C., Wagner, T., Weidner, F., and Pfeilsticker, K.: Inter-comparison of stratospheric $\mathrm{O}_{3}$ and $\mathrm{NO}_{2}$ abundances retrieved from balloon borne direct sun observations and Envisat/SCIAMACHY limb measurements, Atmos. Chem. Phys., 6, 1293-1314, doi:10.5194/acp-61293-2006, 2006. 
Carn, S. A., Clarisse, L., and Prata, A. J.: Multi-decadal satellite measurements of global volcanic degassing, J. Volcanol. Geoth. Res., 311, 99-134, 2016.

Carslaw, K., Luo, B., and Peter, T.: An analytic expression for the composition of aqueous $\mathrm{HNO}_{3}-\mathrm{H}_{2} \mathrm{SO}_{4}$ stratospheric aerosols including gas phase removal of $\mathrm{HNO}_{3}$, Geophys. Res. Lett., 16, 1877-1880, 1995.

Chipperfield, M. P.: Multiannual simulations with a threedimensional chemical transport model, J. Geophys. Res., 104, 1781-1805, 1999.

Clarisse, L., Hurtmans, D., Clerbaux, C., Hadji-Lazaro, J., Ngadi, Y., and Coheur, P.-F.: Retrieval of sulphur dioxide from the infrared atmospheric sounding interferometer (IASI), Atmos. Meas. Tech., 5, 581-594, doi:10.5194/amt-5-581-2012, 2012.

Cox, R. A., MacKenzie, A. R., Müller, R. H., Peter, T., and Crutzen, P. J.: Activation of stratospheric chlorine by reactions in liquid sulphuric acid, Geophys. Res. Lett., 21, 1439-1442, 1994.

Danilin, M. J., Rodriguez, J. M., Hu, W., Ko, M. K. W., Weisenstein, D. K., Kumer, J. B., Mergenthaler, J. L., Russell III, J. M., Koike, M., Yue, G. K., Jones, N. B., and Johnston, P. V.: Nitrogen species in the post-Pinatubo stratosphere: Model analysis utilizing UARS measurements, J. Geophys. Res., 104, 8247-8262, 1999.

Deshler, T., Hervig, M. E., Hofmann, D. J., Rosen, J. M., and Liley, J. B.: Thirty years of in situ stratospheric aerosol size distribution measurements from Laramie, Wyoming $\left(41^{\circ} \mathrm{N}\right)$, using balloon-borne instruments, J. Geophys. Res., 108, 4167, doi:10.1029/2002JD002514, 2003.

Dhomse, S. S., Chipperfield, M. P., Feng, W., Hossaini, R., Mann, G. W., and Santee, M. L.: Revisiting the hemispheric asymmetry in midlatitude ozone changes following the Mount Pinatubo eruption: A 3-D model study, Geophys. Res. Lett., 42, 30383047, doi:10.1002/2015GL063052, 2015.

Dorf, M., Butler, J. H., Butz, A., Camy-Peyret, C., Chipperfield, M. P., Kritten, L., Montzka, S. A., Simmes, B., Weidner, F., and Pfeilsticker, K.: Long-term observations of stratospheric bromine reveal slow down in growth, Geophys. Res. Lett., 33, L24803, doi:10.1029/2006GL027714, 2006a.

Dorf, M., Bösch, H., Butz, A., Camy-Peyret, C., Chipperfield, M. P., Engel, A., Goutail, F., Grunow, K., Hendrick, F., Hrechanyy, S., Naujokat, B., Pommereau, J.-P., Van Roozendael, M., Sioris, C., Stroh, F., Weidner, F., and Pfeilsticker, K.: Balloon-borne stratospheric $\mathrm{BrO}$ measurements: comparison with Envisat/SCIAMACHY BrO limb profiles, Atmos. Chem. Phys., 6, 2483-2501, doi:10.5194/acp-6-2483-2006, 2006b.

Dufour, G., Payan, S., Lefèvre, F., Eremenko, M., Butz, A., Jeseck, P., Té, Y., Pfeilsticker, K., and Camy-Peyret, C.: 4-D comparison method to study the NOy partitioning in summer polar stratosphere - Influence of aerosol burden, Atmos. Chem. Phys., 5, 919-926, doi:10.5194/acp-5-919-2005, 2005.

Erle, F., Grendel, A., Perner, D., Platt, U., and Pfeilsticker, K.: Evidence of heterogeneous chemistry on cold stratospheric sulphate aerosols, Geophys. Res. Lett., 25, 4329-4332, 1998.

ESPRI data Centre: AERIS French atmosphere infrastructure, balloon-borne observations of the StraPolÉté campaign, http:// ether.ipsl.jussieu.fr/etherTypo/index.php?id=1538\&L=1 (last access: 10 February 2017), 2016.

Fahey, D. W. and Ravishankara, A. R.: Summer in the stratosphere, Science, 285, 208-210, 1999.
Fahey, D. W., Kawa, S. R., Woodbridge, E. L., Tin, P., Wilson, J .C., Jonsson, H. H., Dye, J. E., Baumgardner, D., Borrmann, S., Toohey, D. W., Avallone, L. M., Proffitt, M. H., Margitan, J., Loewenstein, M., Podolske, J. R., Salawitch, R. J., Wofsy, S. C., Ko, M. K. W., Anderson, D. E., Schoeberl, M. R., and Chan, K. R.: In situ measurements constraining the role of sulphate aerosols in mid-latitude ozone depletion, Nature, 363, 509-514, 1993.

Ferlemann, F., Camy-Peyret, C., Fitzenberger, R., Harder, H., Hawat, T., Osterkamp, H., Schneider, M., Perner, D., Platt, U., Vradelis, P., and Pfeilsticker, K.: Stratospheric BrO profiles measured at different latitudes and seasons: Instrument description, spectral analysis and profile retrieval, Geophys. Res. Lett., 25, 3847-3850, 1998.

Ferlemann, F., Bauer, N., Fitzenberger, R., Harder, H., Osterkamp, H., Perner, D., Platt, U., Schneider, M., Vradelis, P., and Pfeilsticker, K.: Differential Optical Absorption Spectroscopy Instrument for stratospheric balloon-borne trace gas studies, Appl. Optics, 39, 2377-2386, 2000.

Fischer, H., Birk, M., Blom, C., Carli, B., Carlotti, M., von Clarmann, T., Delbouille, L., Dudhia, A., Ehhalt, D., Endemann, M., Flaud, J. M., Gessner, R., Kleinert, A., Koopman, R., Langen, J., López-Puertas, M., Mosner, P., Nett, H., Oelhaf, H., Perron, G., Remedios, J., Ridolfi, M., Stiller, G., and Zander, R.: MIPAS: an instrument for atmospheric and climate research, Atmos. Chem. Phys., 8, 2151-2188, doi:10.5194/acp-8-2151-2008, 2008.

Gao, R. S., Fahey, D. W., Del Negro, L. A., Donnelly, S. G., Keim, E. R., Neuman, J. A., Teverovskaia, E., Wennberg, P. O., Hanisco, T. F., Lanzendorf, E. J., Proffitt, M. H., Margitan, J. J., Wilson, J. C., Elkins, J. W., Stimpfle, R. M., Cohen, R. C., McElroy, C. T., Bui, T. P., Salawitch, R. J., Brown, S. S., Ravishankara, A. R., Portmann, R. W., Ko, M. K. W., Weisenstein, D. K., and Newman, P. A.: A comparison of observations and model simulations of $\mathrm{NO}_{x} / \mathrm{NO}_{y}$ in the lower stratosphere, Geophys. Res. Lett., 26, 1153-1156, 1999.

Granier., C. and Brasseur, G.: Impact of heterogeneous chemistry on model predictions of ozone changes, J. Geophys. Res., 97, 18015-18033, 1992.

Grossel, A., Huret, N., Catoire, V., Berthet, G., Renard, J.-B., Robert, C., and Gaubicher, B.: In situ balloon-borne measurements of $\mathrm{HNO}_{3}$ and $\mathrm{HCl}$ stratospheric vertical profiles influenced by PSC formation during 2005-2006 Arctic winter, J. Geophys. Res., 115, D21303, doi:10.1029/2009JD012947, 2010.

Hanisco, T. F., Lanzendorf, E. J., Wennberg, P. O., Perkins, K. K., Stimpfle, R. M., Voss, P. B., Anderson, J. G., Cohen, R. C., Fahey, D. W., Gao, R. S., Hintsa, E. J., Salawitch, R. J., Margitan, J. J., McElroy, C. T., and Midwinter, C.: Sources, Sinks, and the Distribution of $\mathrm{OH}$ in the Lower Stratosphere, J. Phys. Chem. A, 2001, 1543-1553, 2001.

Hanson, D. R.: Reactivity of $\mathrm{BrONO}_{2}$ and $\mathrm{HOBr}$ on sulfuric acid solutions at low temperatures, J. Geophys. Res., 108, 4239, doi:10.1029/2002JD002519, 2003.

Hanson, D. R. and Ravishankara, A. R., Heterogeneous chemistry of bromine species in sulfuric acid under stratospheric conditions, Geophys. Res. Lett., 22, 385-388, 1995.

Hanson, D. R., Ravishankara, A. R., and Solomon, S.: Heterogeneous reactions in sulfuric acid aerosols: A framework for model calculations, J. Geophys. Res., 99, 3615-3629, 1994. 
Hanson, D. R., Ravishankara, A. R., and Lovejoy, E. R.: Reaction of $\mathrm{BrONO}_{2}$ with $\mathrm{H}_{2} \mathrm{O}$ on submicron sulfuric acid aerosol and the implications for the lower stratosphere, J. Geophys. Res., 101, 9063-9069, 1996.

Harder, H., Camy-Peyret, C., Ferlemann, F., Fitzenberger, R., Hawat, T., Osterkamp, H., Perner, D., Platt, U., Schneider, M., Vradelis, P., and Pfeilsticker, K.: Stratospheric BrO Profiles Measured at Different Latitudes and Seasons: Atmospheric Observations, Geophys. Res. Lett., 25, 3843-3846, 1998.

Harder, H., Bösch, H., Camy-Peyret, C, Chipperfield, M., Fitzenberger, R., Payan, S., Perner, D., Platt, U., Sinnhuber, B., and Pfeilsticker, K.: Comparison of measured and modeled stratospheric BrO: Implications for the total amount of stratospheric bromine, Geophys. Res. Lett., 27, 3695-3698, 2000.

Harder, J. W., Brault, J. W., Johnston, P. V., and Mount, G. H.: Temperature dependent $\mathrm{NO}_{2}$ cross sections at high spectral resolution, J. Geophys. Res., 102, 3861-3879, 1997.

Hawat, T., Camy-Peyret, C., Jeseck, P., and Torguet, R.: Description and performance of a balloon-borne heliostat for solar absorption measurements, in: 12th ESA Symposium on Rocket and Balloon Programmes and Related Research, 1995.

Haywood, J. M., Jones, A., Clarisse, L., Bourassa, A., Barnes, J., Telford, P., Bellouin, N., Boucher, O., Agnew, P., Clerbaux, C., Coheur, P., Degenstein, D., and Braesicke, P.: Observations of the eruption of the Sarychev volcano and simulations using the HadGEM2 climate model, J. Geophys. Res., 115, D21212, doi:10.1029/2010JD014447, 2010.

Hofmann, D. J. and Solomon, S., Ozone destruction through heterogeneous chemistry following the eruption of El Chichon, J. Geophys. Res., 94, 5029-5041, 1989.

Hofmann, D. J., Oltmans, S. J., Komhyr, W. D., Harris, J. M., Lathrop, J. A., Langford, A. O., Deshler, T., Johnson, B. J., Torress, A., and Matthews, W. A.: Ozone loss in the lower stratosphere over the United States in 1992-1993: Evidence for heterogeneous chemistry on the Pinatubo aerosol, Geophys. Res. Lett., 21, 65-68, 1994.

Hörmann, C., Sihler, H., Bobrowski, N., Beirle, S., Penning de Vries, M., Platt, U., and Wagner, T.: Systematic investigation of bromine monoxide in volcanic plumes from space by using the GOME-2 instrument, Atmos. Chem. Phys., 13, 4749-4781, doi:10.5194/acp-13-4749-2013, 2013.

Jégou, F., Berthet, G., Brogniez, C., Renard, J.-B., François, P., Haywood, J. M., Jones, A., Bourgeois, Q., Lurton, T., Auriol, F., Godin-Beekmann, S., Guimbaud, C., Krysztofiak, G., Gaubicher, B., Chartier, M., Clarisse, L., Clerbaux, C., Balois, J. Y., Verwaerde, C., and Daugeron, D.: Stratospheric aerosols from the Sarychev volcano eruption in the 2009 Arctic summer, Atmos. Chem. Phys., 13, 6533-6552, doi:10.5194/acp-13-6533-2013, 2013.

Johnston, P. V., McKenzie, R. L., Keys, J. G., and Matthews, W. A.: Observations of depleted stratospheric $\mathrm{NO}_{2}$ following the Pinatubo volcanic eruption, Geophys. Res. Lett., 19, 211-213, 1992.

Jucks, K. W., Johnson, D. G., Chance, K. V., Traub, W. A., and Salawitch, R. J.: Nitric acid in the middle stratosphere as a function of altitude and aerosol loading, J. Geophys. Res., 104, 26715-26723, 1999.
Kinnison, D. E., Grant, K. E., Connell, P. S., Rotman, D. A., and Wuebbles, D. J.: The chemical and radiative effects of the Mount Pinatubo eruption, J. Geophys. Res., 99, 25705-25731, 1994.

Koike, M., Kondo, Y., Matthews, W. A., Johnston, P. V., and Yamazaki, K.: Decrease of stratospheric $\mathrm{NO}_{2}$ at $44^{\circ} \mathrm{N}$ caused by Pinatubo volcanic aerosols, Geophys. Res. Lett., 20, 1975-1978, 1993.

Koike, M., Jones, N. B., Matthews, W. A., Johnston, P. V., McKenzie, R. L., Kinnison, D., and Rodriguez, J.: Impact of Pinatubo aerosols on the partitioning between $\mathrm{NO}_{2}$ and $\mathrm{HNO}_{3}$, Geophys. Res. Lett., 21, 597-600, 1994.

Kondo, Y., Sugita, T., Salawitch, R. J., Koike, M., and Deshler, T.: Effect of Pinatubo aerosols on stratospheric NO, J. Geophys. Res., 102, 1205-1213, 1997.

Kondo, Y., Sugita, T., Koike, M., Kawa, S. R., Danilin, M. Y., Rodriguez, J. M., Spreng, S., Golinger, K., and Arnold, F.: Partitioning of reactive nitrogen in the midlatitude lower stratosphere, J. Geophys. Res., 105, 1417-1424, 2000.

Kravitz, B., Robock, A., Bourassa, A., Deshler, T., Wu, D., Mattis, I., Finger, F., Hoffmann, A., Ritter, C., Bitar, L., Duck, T. J., and Barnes, J. E.: Simulation and observations of stratospheric aerosols from the 2009 Sarychev volcanic eruption, J. Geophys. Res., 116, D18211, doi:10.1029/2010JD015501, 2011.

Krecl, P., Haley, C. S., Stegman, J., Brohede, S. M., and Berthet, G.: Retrieving the vertical distribution of stratospheric OClO from Odin/OSIRIS limb-scattered sunlight measurements, Atmos. Chem. Phys., 6, 1879-1894, doi:10.5194/acp-6-1879-2006, 2006.

Kreycy, S., Camy-Peyret, C., Chipperfield, M. P., Dorf, M., Feng, W., Hossaini, R., Kritten, L., Werner, B., and Pfeilsticker, K.: Atmospheric test of the $J\left(\mathrm{BrONO}_{2}\right) / k_{\mathrm{BrO}+\mathrm{NO}_{2}}$ ratio: implications for total stratospheric Bry and bromine-mediated ozone loss, Atmos. Chem. Phys., 13, 6263-6274, doi:10.5194/acp-136263-2013, 2013.

Krysztofiak, G., Thiéblemont, R., Huret, N., Catoire, V., Té, Y., Jégou, F., Coheur, P. F., Clerbaux, C., Payan, S., Drouin, M. A., Robert, C., Jeseck, P., Attié, J.-L., and Camy-Peyret, C.: Detection in the summer polar stratosphere of pollution plume from East Asia and North America by balloon-borne in situ CO measurements, Atmos. Chem. Phys., 12, 11889-11906, doi:10.5194/acp-12-11889-2012, 2012.

Krysztofiak, G., Té, Y. Catoire, V., Berthet, G., Toon, G. C., Jégou, F., Jeseck, P., and Robert, C.: Carbonyl sulfide variability with latitude in the atmosphere, Atmos. Ocean, 53, 89-101, doi:10.1080/07055900.2013.876609, 2015.

Küll, V., Riese, M., Tie, X., Wiemert, T., Eidmann, G., Offermann, D., and Brasseur, G. P.: $\mathrm{NO}_{y}$ partitioning and aerosol influences in the stratosphere, J. Geophys. Res., 107, 8183, doi:10.1029/2001JD001246, 2002.

Lary, D. J., Chipperfield, M. P., Toumi, R., and Lenton, T.: Heterogeneous atmospheric bromine chemistry, J. Geophys. Res., 101, 1489-1504, 1996.

Lefèvre, F., Brasseur, G. P., Folkins, I., Smith, A. K., and Simon, P.: Chemistry of the 1991-1992 stratospheric winter: Threedimensional model simulations, J. Geophys. Res., 99, 91838195, 1994.

Lefèvre, F., Figarol, F., Carslaw, K., and Peter, T.: The 1997 Arctic ozone depletion quantified from three-dimensional model simulations, Geophys. Res. Lett., 25, 2425-2428, 1998. 
Legras, B., Pisso, I., Berthet, G., and Lefèvre, F.: Variability of the Lagrangian turbulent diffusion in the lower stratosphere, Atmos. Chem. Phys., 5, 1605-1622, doi:10.5194/acp-5-1605-2005, 2005.

Livesey, N. J., Read, W. G., Froidevaux, L., Lambert, A., Manney, G. L., Pumphrey, H. C., Santee, M. L., Schwartz, M. J., Wang, S., Cofield, R. E., Cuddy, D. T., Fuller, R. A., Jarnot, R. F., Jiang, J. H., Knosp, B. W., Stek, P. C., Wagner, P. A., and Wu, D. L.: Earth Observing System (EOS) Aura Microwave Limb Sounder (MLS) Version 3.3 and 3.4 Level 2 Data Quality and Description Document. Tech. Rep. JPL D-33509. NASA Jet Propulsion Laboratory, California Institute of Technology, Pasadena, California (91109-8099), available at: http://mls.jpl.nasa.gov/data/datadocs. php (last access: 9 February 2017), 2011.

McElroy, M. B., Salawitch, R. J., and Minschwaner, K.: The changing stratosphere, Planet. Space. Sci., 40, 373-401, 1992.

McGee, T. J., Newman, P., Gross, M., Singh, U., Godin, S., Lacoste, A.-M., and Mégie, G.: Correlation of ozone loss with the presence of volcanic aerosols, Geophys. Res. Lett., 21, 2801-2804, 1994.

Mébarki, Y., Catoire, V., Huret, N., Berthet, G., Robert, C., and Poulet, G.: More evidence for very short-lived substance contribution to stratospheric chlorine inferred from $\mathrm{HCl}$ balloon-borne in situ measurements in the tropics, Atmos. Chem. Phys., 10, 397-409, doi:10.5194/acp-10-397-2010, 2010.

Michelsen, H. A., Manney, G. L., Gunson, M. R., and Zander, R.: Correlations of stratospheric abundances of $\mathrm{NO}_{y}, \mathrm{O}_{3}, \mathrm{~N}_{2} \mathrm{O}$, and $\mathrm{CH}_{4}$ derived from ATMOS measurements, J. Geophys. Res., 103, 28347-28359, 1998.

Michelsen, H. A., Spivakovsky, C. M., and Wofsy, S. C.: Aerosolmediated partitioning of stratospheric $\mathrm{Cl}_{y}$ and $\mathrm{NO}_{y}$ at temperatures above 200 K, Geophys. Res. Lett., 26, 299-302, 1999.

Mills, M. J., Langford, A. O., O’Leary, T. J., Arpag, K., Miller, H. L., Proffitt, M. H., Sander, R. W., and Solomon, S.: On the relationship between stratospheric aerosols and nitrogen dioxide, Geophys. Res. Lett., 20, 1187-1190, 1993.

Moreau, G., Robert, C., Catoire, V., Chartier, M., Camy-Peyret, C., Huret, N., Pirre, M., and Pomathiod, L.: A multi-species in situ balloon-borne instrument with six diode laser spectrometers, Appl. Optics, 44, 1-18, 2005.

Newchurch, M. J., Allen, M., Gunson, M. R., Salawitch, R. J., Collins, G. B., Huston, K. H., Abbas, M. M., Abrams, M. C., Chang, A. Y., Fahey, D. W., Gao, R. S., Irion, F. W., Loewenstein, M., Manney, G. L., Michelsen, H. A., Podolske, J. R., Rinsland, C. P., and Zander, R.: Stratospheric $\mathrm{NO}$ and $\mathrm{NO}_{2}$ abundances from ATMOS solar-occultation measurements, Geophys. Res. Lett., 23, 2373-2376, 1996.

O’Neill, N. T., Perro, C., Saha, A., Lesins, G., Duck, T. J., Eloranta, E. W., Nott, G. J., Hoffman, A., Karumudi, M. L., Ritter, C., Bourassa, A., Abboud, I., Carn, S. A., and Savastiouk, V.: Properties of Sarychev sulphate aerosols over the Arctic, J. Geophys. Res., 117, D04203, doi:10.1029/2011JD016838, 2012.

Osterman, G. B., Sen, B. Toon, G. C., Salawitch, R. J., Margitan, J. J., and Blavier, J.-F.: Partitioning of $\mathrm{NO}_{y}$ species in the summer Arctic stratosphere, Geophys. Res. Lett., 26, 1157-1160, 1999.

Ovarlez, J. and Ovarlez, H.: Water vapour and aerosol measurements during SESAME, and the observation of low water vapour content layers, in Polar Stratospheric Ozone, proceedings of the Third European Workshop, Air Pollution Rep. 56, edited by:
Pyle, J. A., Harris, N. R. P., and Amanatidis, G. T., European Commission, Luxembourg, 205-208, 1995.

Payan, S., Camy-Peyret, C., Jeseck, P., Hawat, T., Pirre, M., Renard, J.-B., Robert, C., Lefèvre, F., Kanzawa, H., and Sasano, Y.: Diurnal and nocturnal distribution of stratospheric $\mathrm{NO}_{2}$ from solar and stellar occultation measurements in the Arctic vortex: comparison with models and ILAS satellite measurements, J. Geophys. Res., 104, 21585-21593, 1999.

Pfeilsticker, K., Sturges, W. T., Bösch, H., Camy-Peyret, C., Chipperfield, M. P., Engel, A., Fitzenberger, R., Müller, M., Payan, S., and Sinnhuber, B.-M.: Lower stratospheric organic and inorganic bromine budget for the Artic winter 1998/99, Geophys. Res. Lett., 27, 20, 3305-3308, 2000.

Pitari, G. and Rizi, V.: An estimate of the chemical and radiative perturbation of stratospheric ozone following the eruption of Mt. Pinatubo, J. Atmos. Sci., 50, 3260-3276, 1993.

Pitari, G., Aquila, V., Kravitz, B., Robock, A., Watanabe, S., Cionni, I., De Luca, N., Di Genova, G., Mancini, E., and Tilmes, S.: Stratospheric response to sulfate geoengineering: Results from the Geoengineering Model Intercomparison Project (GeoMIP), J. Geophys. Res., 119, 2629-2653, 2014.

Platt, U.: Differential optical absorption spectroscopy (DOAS), in Air Monitoring by Spectroscopic Techniques, edited by: Sigrist, M. W., Vol. 127, Chemical Analysis Series, Wiley, New York, 27-84, 1994.

Pommereau, J.-P. and Piquard, J.: Ozone and nitrogen dioxide vertical distributions by UV-visible solar occultation from balloons, Geophys. Res. Lett., 21, 1227-1230, 1994.

Portmann, R. W., Brown, S. S., Gierczak, T., Talukdar, R. K., Burkholder, J. B., and Ravishankara, A. R.: Role of nitrogen oxides in the stratosphere: a reevaluation based on laboratory studies, Geophys. Res. Lett., 26, 2387-2390, 1999.

Prasad, S. S.: A modeling study of the stratospheric $\mathrm{NO}_{x} / \mathrm{NO}_{y}$ and $\mathrm{NO}_{x} / \mathrm{HNO}_{3}$ ratios: Single- versus dual-channeled mode of $\mathrm{OH}, \mathrm{NO}_{2}$ association, J. Geophys. Res., 108, 4474, doi:10.1029/2002JD002970, 2003.

Prather, M.: Catastrophic loss of stratospheric ozone in dense volcanic clouds, J. Geophys. Res., 97, 10187-10191, 1992.

Randeniya, L. K., Vohralik, P. F., Plumb, I. C., and Ryan, K. R.: Heterogeneous $\mathrm{BrONO}_{2}$ hydrolysis: effect on $\mathrm{NO}_{2}$ columns and ozone at high latitudes in summer, J. Geophys. Res., 102, 2354323557, 1997.

Renard, J.-B., Chartier, M., Robert, C., Chalumeau, G., Berthet, G., Pirre, M., Pommereau, J. P., and Goutail, F.: SALOMON: a new, light balloon borne UV-visible spectrometer for nighttime observations of stratospheric trace-gas species, Appl. Optics, 39, 386392, 2000.

Renard, J.-B., Taupin, F. G., Rivière, E. D., Pirre, M., Huret, N., Berthet, G., Robert, C., Chartier, M., Pepe, F., and George, M.: Measurements and simulation of stratospheric $\mathrm{NO}_{3}$ at Mid- and High-latitudes in the Northern Hemisphere, J. Geophys. Res., 106, 32387-32399, 2001.

Renard, J.-B., Berthet, G., Robert, C., Chartier, M., Pirre, M., Brogniez, C., Herman, M., Verwaerde, C., Balois, J.-Y., Ovarlez, J., Ovarlez, H., Crespin, J., and Deshler, T.: Optical and physical properties of stratospheric aerosols from balloon measurements in the visible and near-infrared domain: II. Comparison of extinction, reflectance, polarization and counting measurements, Appl. Optics, 41, 7540-7549, 2002. 
Renard, J.-B., Ovarlez, J., Berthet, G., Fussen, B., Vanhellemont, F., Brogniez, C., Hadamcik, E., Chartier, M., and Ovarlez, H.: Optical and physical properties of stratospheric aerosols from balloon measurements in the visible and near-infrared domains. III. Presence of aerosols in the middle stratosphere, Appl. Optics, 44, 4086-4095, doi:10.1364/AO.44.004086, 2005.

Renard, J.-B., Brogniez, C., Berthet, G., Bourgeois, Q., Gaubicher, B., Chartier, M., Balois, J.-Y., Verwaerde, C., Auriol, F., François, P., Daugeron, D., and Engrand, C.: Vertical distribution of the different types of aerosols in the stratosphere, Detection of solid particles and analysis of their spatial variability, J. Geophys. Res., 113, D21303, doi:10.1029/2008JD010150, 2008.

Renard, J.-B., Berthet, G, Salazar, S., Catoire, V., Tagger, T., Gaubicher, B., and Robert, C: In situ detection of aerosol layers in the middle stratosphere, Geophys. Res. Lett., 37, L20803, doi:10.1029/2010GL044307, 2010.

Rinsland, C. P., Weisenstein, D. K., Ko, M. K. W., Scott, C. J., Chiou, L. S., Mahieu, E., Znader, R., and Demoulin, P.: PostMount Pinatubo eruption ground-based infrared stratospheric column measurements of $\mathrm{HNO}_{3}, \mathrm{NO}$, and $\mathrm{NO}_{2}$ and their comparison with model calculations, J. Geophys. Res., 108, 4437, doi:10.1029/2002JD002965, 2003.

Rivière, E. D., Pirre, M., Berthet, G., Renard, J.-B., and Lefèvre, F.: Investigating the $\mathrm{OClO}$ and $\mathrm{Br}_{y}$ chemistry from high-latitude nighttime measurements of $\mathrm{OClO}$ and $\mathrm{NO}_{2}$, J. Atmos. Chem., 48, 261-282, 2004.

Robock, A.: Volcanic eruptions and climate, Rev. Geophys., 38, 191-219, 2000.

Rodgers, C.: Inverse methods for atmospheric sounding, World Scientific, Singapore, New Jersey, London, Hongkong, 2000.

Rodriguez, J. M., Ko, M. K. W., and Sze, N. D.: Role of heterogeneous conversion of $\mathrm{N}_{2} \mathrm{O}_{5}$ on sulphate aerosols in global ozone losses, Nature, 352, 134-137, 1991.

Rothman, L. S., Gordon, I. E., Babikov, Y., Barbe, A., Benner, D. C., Bernath, P. F., Birk, M., Bizzocchi, L., Boudon, V., Brown, L. R., Campargue, A., Chance, K., Cohen, E. A., Coudert, L. H., Devi, V. M., Drouin, B. J., Fayt, A., Flaud, J.-M., Gamache, R. R., Harrisonn, J. J., Hartmann, J.-M., Hill, C., Hodges, J. T., Jacquemart, D., Jolly, A., Lamouroux, J., Le Roy, R. G., Li, G., Long, D. A., Lyulin, O. M., Mackie, C. J., Massie, S. T., Mikhailenko, S., Müller, H. S. P., Naumenko O. V., Nikitin, A. V., Orphal, J., Perevalov, V., Perrin, A., Polovtseva, E. R., Richard, C., Smith, M. A. H., Starikova, E., Sungi, K., Tashkun, S., Tennyson, J., Toon, G. C., Tyuterev, VI. G., and Wagner, G.: The HITRAN2012 molecular spectroscopic database, J. Quant. Spectrosc. Ra., 130, 4-50, doi:10.1016/j.jqsrt.2013.07.002, 2013.

Salawitch, R. J., Wofsy, S. C., Wennberg, P. O., Cohen, R. C., Anderson, J. G., Fahey, D. W., Gao, R. S., Keim, E. R., Woodbridge, E. L., Stimpfle, R. M., Koplow, J. P., Kohn, D. W., Webster, C. R., May, R. D., Pfister, L., Gottlieb, E. W., Michelsen, H. A., Yue, G. K., Wilson, J. C., Brock, C. A., Jonsson, H. H., Dye, J. E., Baumgardner, D., Proffitt, M. H., Loewenstein, M., Podolske, J. R., Elkins, J. W., Dutton, G. S., Hintsa, E. J., Dessler, A. E., Weinstock, E. M., Kelly, K. K., Boering, K. A., Daube, B. C., Chan, K. R., and Bowen, S. W.: The distribution of hydrogen, nitrogen, and chlorine radicals in the lower stratosphere: Implications for changes in $\mathrm{O}_{3}$ due to emission of $\mathrm{NO}_{y}$ from supersonic aircraft, Geophys. Res. Lett., 21, 2547-2550, 1994a.
Salawitch, R. J., Wofsy, S. C., Wennberg, P. O., Cohen, R. C., Anderson, J. G., Fahey, D. W., Gao, R. S., Keim, E. R., Woodbridge, E. L., Stimpfle, R. M., Koplow, J. P., Kohn, D. W., Webster, C. R., May, R. D., Pfister, L., Gottlieb, E. W., Michelsen, H. A., Yue, G. K., Wilson, J. C., Brock, C. A., Jonsson, H. H., Dye, J. E., Baumgardner, D., Proffitt, M. H., Loewenstein, M., Podolske, J. R., Elkins, J. W., Dutton, G. S., Hintsa, E. J., Dessler, A. E., Weinstock, E. M., Kelly, K. K., Boering, K. A., Daube, B. C., Chan, K. R., and Bowen, S. W.: The diurnal variation of hydrogen, nitrogen, and chlorine radicals: Implications for the heterogeneous production of $\mathrm{HNO}_{2}$, Geophys. Res. Lett., 21, 25512554, 1994b.

Salawitch, R. J., Weisenstein, D. K., Kovalenko, L. J., Sioris, C. E., Wennberg, P. O., Chance, K., Ko, M. K. W., and McLinden, C. A.: Sensitivity of ozone to bromine in the lower stratosphere, Geophys. Res. Lett., 32, L05811, doi:10.1029/2004GL021504, 2005.

Sander, S. P., Abbatt, J. P. D., Friedl, R. R., Barker, J. R., Burkholder, J. B., Golden, D. M., Kolb, C. E., Kurylo, M. J., Moortgat, G. K., Wine, P. H., Huie, R. E., and Orkin, V. L.: Chemical kinetics and photochemical data for use in atmospheric studies, Evaluation number 17, JPL Publ., 10-6, 684 pp., 2011.

Santee, M. L., Manney, G. L., Livesey, N. J., and Read, W. G.: Three-dimensional structure and evolution of stratospheric $\mathrm{HNO}_{3}$ based on UARS Microwave Limb Sounder measurements, J. Geophys. Res., 109, D15306, doi:10.1029/2004JD004578, 2004.

Sen, B., Toon, G. C., Osterman, G. B., Blavier, J.-F., Margitan, J. J., Salawitch, R. J., and Yue, G. K.: Measurements of reactive nitrogen in the stratiosphere, J. Geophys. Res., 103, 3571-3585, 1998.

Shi, Q., Jayne, J. T., Kolb, C. E., and Worsnop, D. R.: Kinetic model for reaction of $\mathrm{ClONO}_{2}$ with $\mathrm{H}_{2} \mathrm{O}$ and $\mathrm{HCl}$ and $\mathrm{HOCl}$ with $\mathrm{HCl}$ in sulfuric acid solutions, J. Geophys. Res., 106, 24259-24274, 2001.

Solomon, S.: Stratospheric ozone depletion: a review of concepts and history, Rev. Geophys., 37, 275-316, 1999.

Solomon, S., Sanders, R. W., Jakoubek, R. O., Arpag, K. H., Stephens, S. L., Keys, J. G., and Garcia, R. R.: Visible and nearultraviolet spectroscopy at McMurdo Station, Antarctica. 10. Reductions of stratospheric $\mathrm{NO}_{2}$ due to Pinatubo aerosols, J. Geophys. Res., 99, 3509-3516, 1994.

Solomon, S., Portmann, R. W., Garcia, R. R., Thomason, L. W., Poole, L. R., and McCormick, M. P.: The role of aerosol variations in anthropogenic ozone depletion at northern midlatitudes, J. Geophys. Res., 101, 6713-6727, 1996.

Solomon, S., Ivy, D. J., Kinnison, D., Mills, M. J., Neely III, R. R., and Schmidt, A.: Emergence of healing in the Antarctic ozone layer, Science, 353, 269-274, 2016.

Steele, H. M. and Turco, R. P.: Retrieval of aerosol size distributions from satellite extinction spectra using constrained linear inversion, J. Geophys. Res., 102, 16737-16747, 1997.

Stutz, J. and Platt, U.: Numerical analysis and estimation of the statistical error of differential optical absorption spectroscopy measurements with least squares methods, Appl. Optics, 35, 60416053, 1996.

Tabazadeh, A., Toon, O. B., Clegg, S. L., and Hamill, P.: A new parameterization of $\mathrm{H}_{2} \mathrm{SO}_{4} / \mathrm{H}_{2} \mathrm{O}$ aerosol composition: Atmospheric implications, Geophys. Res. Lett., 24, 1931-1934, 1997. 
Telford, P., Braesicke, P., Morgenstern, O., and Pyle, J.: Reassessment of causes of ozone column variability following the eruption of Mount Pinatubo using a nudged CCM, Atmos. Chem. Phys., 9, 4251-4260, doi:10.5194/acp-9-4251-2009, 2009.

Tie, X. and Brasseur, G.: The response of stratospheric ozone to volcanic eruptions: Sensitivity to atmospheric chlorine loading, Geophys. Res. Lett., 22, 3035-3038, 1995.

Tie, X. and Brasseur, G. P.: The importance of heterogeneous bromine chemistry in the lower stratosphere, Geophys. Res. Lett., 23, 2505-2508, 1996.

Tie, X., Brasseur, G. P., Briegleb, B., and Granier, C., Twodimensional simulation of Pinatubo aerosol and its effect on stratospheric ozone, J. Geophys. Res., 99, 20545-20562, 1994.

Van de Hulst, H. C.: Light Scattering By Small Particles, John Wiley \& Sons, Inc., New York, 1957.

Vernier, J.-P., Thomason, L. W., Pommereau, J.-P., Bourassa, A., Pelon, J., Garnier, A., Hauchecorne, A., Blanot, L., Trepte, C., Degenstein, D., and Vargas, F.: Major influence of tropical volcanic eruptions on the stratospheric aerosol layer during the last decade, Geophys. Res. Lett., 38, L12807, doi:10.1029/2011GL047563, 2011.

Voigt, S., Orphal, J., Bogumil, K., and Burrows, J. P.: The temperature dependence (203-293 K) of the absorption cross section of $\mathrm{O}_{3}$ in the $230-850 \mathrm{~nm}$ region measured by Fourier-transform spectroscopy, J. Photoch. Photobio. A, 143, 1-9, 2001.

Wahner, A., Ravishankara, A., Sander, S., and Friedl, R.: Absorption cross section of $\mathrm{BrO}$ between 312 and $385 \mathrm{~nm}$ at 298 and 223 K, Chem. Phys. Lett., 152, 507-512, 1988.

Webster, C. R., May, R. D., Allen, M., Jaeglé, L., and McCormick M. P.: Balloon profiles of stratospheric $\mathrm{NO}_{2}$ and $\mathrm{HNO}_{3}$ for testing the heterogeneous hydrolysis of $\mathrm{N}_{2} \mathrm{O}_{5}$ on sulfate aerosols, Geophys. Res. Lett., 21, 53-56, 1994.

Webster, C. R., May, R. D., Michelsen, H. A., Scott, D. C., Wilson, J. C., Jonsson, H. H., Brock, C. A., Dye, J. E., Baumgarnder, D., Stimpfle, R. M., Koplow, J. P., Margitan, J. J., Proffitt, M. H., Jaeglé, L., Herman, R. L., Hu, H., Flesch, G. J., and Loewenstein, M.: Evolution of $\mathrm{HCl}$ concentrations in the lower stratosphere from 1991 to 1996 following the eruption of Mt. Pinatubo, Geophys. Res. Lett., 25, 995-998, 1998.

Webster, C. R., Michelsen, H. A., Gunson, M. R., Margitan, J. J., Russell III, J. M., Toon, G. C., and Traub, W. A., J.: Response of lower stratospheric $\mathrm{HCl} / \mathrm{Cl}_{y}$ to volcanic aerosols: Observations from aircraft, balloon, space shuttle, and satellite instruments, J. Geophys. Res., 105, 11711-11719, 2000.
Weisenstein, D. K. and Bekki, S.: Modeling of stratospheric aerosols, Assessment of Stratospheric Aerosol Properties (ASAP), chap. 6, WCRP-124, WMO/TD, No. 1295, SPARC Report No. 4, 2006.

Weisenstein, D. K., Ko, M. K. W., Rodriguez, J. M., and Sze, N.-D.: Impact of heterogeneous chemistry on model-calculated ozone change due to high speed civil transport aircraft, Geophys. Res. Lett., 18, 1991-1994, 1991.

Wennberg, P. O., Cohen, R. C., Stimpfle, R. M., Koplow, J. P., Anderson, J. G., Salawitch, R. J., Fahey, D. W., Woodbridge, E. L., Keim, E. R., Gao, R. S., Webster, C. R., May, R. D., Toohey, D. W., Avallone, L. M., Proffitt, M. H., Loewenstein, M., Podolske, J. R., Chan, K. R., and Wofsy, S. C.: Removal of stratospheric $\mathrm{O}_{3}$ by radicals: in situ measurements of $\mathrm{OH}, \mathrm{HO}_{2}, \mathrm{NO}, \mathrm{NO}_{2}, \mathrm{ClO}$ and BrO, Science, 266, 398-404, 1994.

Wennberg, P. O., Hanisco, T. F., Cohen, R. C., Stimpfle R. M., Lapson, L. B., and Anderson, J .G.: In situ measurements of $\mathrm{OH}$ and $\mathrm{HO}_{2}$ in the upper troposphere and stratosphere, J. Atmos. Sci., 52, 3413-3420, 1995.

Wetzel, G., Oelhaf, H., Ruhnke, R., Friedl-Vallon, F., Kleinert, A., Kouker, W., Maucher, G., Reddmann, T., Seefeldner, M. Stowasser, M., Trieschmann, O., Von Clarmann, T., and Fischer, $\mathrm{H}$.: $\mathrm{NO}_{y}$ partitioning and budget and its correlation with $\mathrm{N}_{2} \mathrm{O}$ in the Arctic vortex and in summer midlatitudes in 1997, J. Geophys. Res., 107, 4280, doi:10.1029/2001JD000916, 2002.

Willeke, K. and Liu, B. Y. H.: Single particle optical counter: principle and application, in Fine Particles, Aerosol Generation, Measurement, Sampling and Analysis, edited by: Liu, B. Y. H., Academic, Orlando, Florida, 698-729, 1976.

Wiscombe, W. J.: Improved Mie scattering algorithms, Appl. Optics, 19, 1505-1509, 1980.

World Meteorological Organization (WMO): Scientific Assessment of Ozone Depletion, Report No. 50, Global Ozone Research and Monitoring Project, Geneva, 2010.

World Meteorological Organization (WMO): Scientific Assessment of Ozone Depletion, Report No. 52, Global Ozone Research and Monitoring Project, Geneva, 2014. 